\title{
Phenolic Profile of Potentilla anserina L. (Rosaceae) Herb of Siberian Origin and Development of a Rapid Method for Simultaneous Determination of Major Phenolics in P. anserina Pharmaceutical Products by Microcolumn RP-HPLC-UV
}

\author{
Daniil N. Olennikov ${ }^{1, *}$, Nina I. Kashchenko ${ }^{1}$, Nadezhda K. Chirikova ${ }^{2}$ and \\ Sargylana S. Kuz'mina ${ }^{2}$
}

1 Institute of General and Experimental Biology, Siberian Division, Russian Academy of Science, Sakh’yanovoy str., 6, Ulan-Ude 670047, Russia; E-Mail: ninkk@mail.ru

2 Department of Biochemistry and Biotechnology, North-Eastern Federal University, 58 Belinsky Str., Yakutsk 677-027, Russia; E-Mails: hofnung@mail.ru (N.K.C.); sskuzmina@bk.ru (S.S.K.)

* Author to whom correspondence should be addressed; E-Mail: olennikovdn@mail.ru;

Tel.: +7-9021-600-627; Fax: +7-3012-434-543.

Academic Editor: Derek J. McPhee

Received: 20 November 2014 / Accepted: 22 December 2014 / Published: 24 December 2014

\begin{abstract}
A chemical study of Potentilla anserina L. herb (Rosaceae) of Siberian origin led to the isolation of 17 compounds. Three ellagitannins - potentillin, agrimonic acid A and $\mathrm{B}$ - are reported for the first time in this species. With a view to rapid quantitative analysis, a new method was developed for simultaneous determination of major phenolic compounds in $P$. anserina, including caffeic acid, myricetin-3-O-glucuronide, agrimoniin, ellagic acid, miquelianin, isorhamnetin-3-O-glucuronide, and kaempferol-3-O-rhamnoside. The quantitative determination was conducted by microcolumn reversed phase high-performance liquid chromatography with UV detection. Separation was performed using a ProntoSIL-120-5-C18 AQ column $(60 \mathrm{~mm} \times 1 \mathrm{~mm} \times 5 \mu \mathrm{m})$ with six-step gradient elution of aqueous $0.2 \mathrm{M} \mathrm{LiClO}_{4}$ in $0.006 \mathrm{M} \mathrm{HClO}_{4}$ and acetonitrile as mobile phases. The components were quantified by HPLC-UV at $270 \mathrm{~nm}$. All calibration curves showed good linearity $\left(r^{2}>0.999\right)$ within test ranges. The reproducibility was evaluated by intra- and inter-day assays, and RSD values were less than $2.8 \%$. The recoveries were between 97.15 and $102.38 \%$. The limits of detection ranged from 0.21 to $1.94 \mu \mathrm{g} / \mathrm{mL}$, and limits of quantification ranged from 0.65 to $5.88 \mu \mathrm{g} / \mathrm{mL}$, respectively. Various solvents, extraction methods, temperatures, and times were evaluated to obtain the best extraction efficiency.
\end{abstract}


The developed method was successfully applied for the analysis of selected pharmaceutical products: 12 batches of $P$. anserina herb collected from three Siberian regions (Yakutia, Buryatia, Irkutsk), two commercial samples of $P$. anserina herb, and some preparations (liquid extract, tincture, decoction, infusion, and dry extract).

Keywords: Potentilla anserina; Rosaceae; microcolumn RP-HPLC-UV; agrimoniin; flavonoids; quality control

\section{Introduction}

Potentilla anserina L. (silverweed) is a low-growing herbaceous plant of the Rosaceae family. It is found in the temperate zone around the globe and most commonly on sandy or rocky clay soils in Europe, Siberia, the Far East, and Central Asia. Remedies containing P. anserina total herb are widely used in various folk and medical systems, particularly in traditional Tibetan medicine and folk medicine. In Tibetan medicine, $P$. anserina herb is used for infectious diarrhea with fever, while its roots and rhizomes are applied as an antiseptic remedy [1,2]. In Yakutian medicine, the tincture from $P$. anserina flowers in vodka is used as an antidiarrheal remedy; the water decoction from flowers and leaves is applied for kidney and liver diseases, respectively. The gruel from the fresh leaves is used as a wound-healing agent [3]. In Chinese medicine, the whole plant is applied for the treatment of hematemesis [4]. Traditionally, Mongolian arats (cattle-breeders) applied P. anserina as an astringent and bactericidal remedy for treatment of enterocolitis and dyspepsia [5].

As a result of phytochemical investigations, the presence of the following compounds in the herb of P. anserina was established: catechins (catechin, gallocatechin [6], epigallocatechin, epicatechin, ellagic acid [7]); ellagitannins (agrimoniin, pedunculagin [8]); phenolic acids (gallic, $p$-hydroxybenzoic, vanillic, gentizic, $p$-hydroxyphenylacetic, $p$-coumaric, caffeic, ferulic [9], chlorogenic acids [10]); coumarins (umbelliferon, scopoletin [11]); flavonoids (myricetin [12], myricetin-3-O- $\beta$-D-glucuronide, myricitrin, isorhamnetin-3-O- $\beta$-D-glucuronide, isoquercitrin, reynoutrin, quercitrin, quercetin-3- $O-\beta-\mathrm{D}$-sambubioside, miquelianin, astragalin, tiliroside, 8-methoxykaempferol-3-O-sophoroside [6], rutin, nicotoflorin, linarin [10]); isoflavones (genistein [10]); pyrones (2-pyrone-4,6-dicarboxylic acid [13]); aliphatic compounds (nonacosane, ceryl alcohol, arachidic, cerotic, palmitic, myristic, linoleic, linolenic and oleic acids [14]); and polysaccharides [15]. According to known data about the chemical constituents of $P$. anserina, the occurrence of different classes of phenolic compounds was previously reported for plant material collected in Europe (Poland, Germany, Italy, Ukraine) [6-13]. There is currently no information about the chemical composition of $P$. anserina growing in Siberia.

A great deal of pharmacological studies (in vitro, in vivo, clinical trials) have generally confirmed the traditional use of $P$. anserina and its extracts from aerial and/or underground parts for cardioprotective [16,17], hepatoprotective [18], spasmolytic [19], immunomodulatory [20], antiviral [21], antimutagenic [22,23], antimicrobial [24], antiradical [25], antihypoxic [26,27], and anti-inflammatory [28] remedies. Phenolic compounds are considered a biologically active group of metabolites possessing anti-inflammatory [28], antioxidant, and antibacterial activity [25] of $P$. anserina formulations. 
Given the importance of quantitative analysis of the main phenolic components in P. anserina herb, some authors have suggested different variants of chromatographic analysis applied to HPLC assay, viz. HPLC-UV and HPLC-DAD (Table 1). In all of the proposed methods, reversed-phase sorbents and gradient elution were used for the separation of different classes of $P$. anserina metabolites. The known HPLC techniques used in quantitative analysis of phenolic compounds used NanoLC-Orbitrap-MS [10] and UHPLC-DAD-MS/MS [28]. All mentioned methods were purposed for simultaneous determination of flavonoids and phenylpropanoids [29], tannins and catechins [8], or flavonoids and catechins [7]. There is no HPLC technique allowing one to analyze the quantitative content of the major phenolic groups in $P$. anserina herb: ellagitannins, flavonoids and phenylpropanoids.

In the last decade, miniaturized separation techniques have become greatly popular in pharmaceutical analysis. Miniaturized separation methods are increasingly utilized in all processes of drug discovery as well as the quality control of pharmaceutical preparation [30]. The very low sample required per analysis, reduced analysis time, and the concern about environmental pollution have pushed the use of miniaturized techniques. The range of analysis time in the known variants of HPLC assays of $P$. anserina was from $32 \mathrm{~min}$ to $120 \mathrm{~min}$. In order to reduce the analysis time, we examined the possibility of developing a rapid and validated method for simultaneous determination of major phenolics in P. anserina herb by microcolumn RP-HPLC-UV. Moreover, we realized chemical examination of $P$. anserina herb of the Siberian origin and some $P$. anserina pharmaceutical products.

\section{Results and Discussion}

\subsection{Phenolic Profile of P. anserina Growing in Siberia}

At the preliminary stage of the study we examined the phenolic profile of $P$. anserina collected in the Yakutian region of Siberia. The $60 \% \mathrm{MeOH}$-extract of $P$. anserina herb was partitioned with $\mathrm{CHCl}_{3}$, EtOAc, and $n-\mathrm{BuOH}$ to yield three fractions, which were separated by column chromatography (silica gel, Amberlite XAD7HP, polyamide, Sephadex LH-20 chromatography) and prep. HPLC, to give 17 compounds, with nine being flavonoids [myricetin-3-O- $\beta$-D-glucuronopyranoside (i), rutin (quercetin-3-O-rutinoside; (ii), isoquercitrin (quercetin-3- $O-\beta$-D-glucopyranoside; (iii), miquelianin (quercetin-3-O- $\beta$-D-glucuronopyranoside; (iv), reynoutrin (quercetin-3-O- $\beta$-D-xylopyranoside; (v), quercitrin (quercetin-3- $O$ - $\alpha$-L-rhamnopyranoside; (vi), isorhamnetin-3- $O$ - $\beta$-D-glucopyranoside (vii), isorhamnetin-3-O- $\beta$-D-glucuronopyranoside (viii), kaempferol-3- $O$ - $\alpha$-L-rhamnopyranoside (ix)]. Additionally, four ellagitannins [potentillin (x), agrimonic acid A (xi), agrimonic acid B (xii), agrimoniin (xiii)], caffeic acid (xiv), 3-O-caffeoylquinic acid (xv), ellagic acid (xvi), 2-pyrone-4,6-dicarboxylic acid (xvii) were isolated and identified by comparison of their m.ps, optical rotation values, UV, ${ }^{1} \mathrm{H}$ - and ${ }^{13} \mathrm{C}$-NMR spectroscopic, and MS data with those reported in the literature and reference samples (Figure 1). 
Table 1. Known HPLC assays for analysis of $P$. anserina components.

\begin{tabular}{|c|c|c|c|c|}
\hline Method [ref.] & Compound(s) & Column & Mobile Phases & $\begin{array}{l}\text { Analysis } \\
\text { Time, min }\end{array}$ \\
\hline \multicolumn{5}{|l|}{ Quantitative techniques } \\
\hline HPLC-UV [13] & 2-Pyrone-4,6-dicarboxylic acid & ProSep C-18 $(150 \mathrm{~mm} \times 4 \mathrm{~mm} \times 5 \mu \mathrm{m})$ & $\mathrm{MeCN}, 0.1 \%$ TFA & 45 \\
\hline HPLC-UV [29] & Caffeic acid, ferulic acid, quercetin, rutin & Spherisorb $^{\circledR}$ ODS2 $(250 \mathrm{~mm} \times 4.6 \mathrm{~mm} \times 5 \mu \mathrm{m})$ & $\begin{array}{l}1 \% \mathrm{AcOH}, 6 \% \\
\mathrm{AcOH}, \\
5 \% \mathrm{AcOH} \text { in } 30 \% \\
\mathrm{MeCN}\end{array}$ & 120 \\
\hline HPLC-UV [8] & $\begin{array}{l}\text { Gallic acid, pedunculagin, catechin, ellagic acid, } \\
\text { agrimoniin }\end{array}$ & Chromolith Performance RP-18e $(100 \mathrm{~mm} \times 4.6 \mathrm{~mm})$ & $\begin{array}{l}0.2 \% \mathrm{HCOOH} \\
0.2 \% \mathrm{HCOOH} \text { in } \\
\mathrm{MeCN}\end{array}$ & 32 \\
\hline HPLC-DAD [7] & $\begin{array}{l}\text { Epigallocatechin, catechin, epicatechin, rutin, } \\
\text { isoquercitrin, isorhamnetin-3- } O \text {-glucoside, } \\
\text { kaempferol-3-O-glucoside, ellagic acid }\end{array}$ & Supelco LC RP $18(250 \mathrm{~mm} \times 4.6 \mu \mathrm{m} \times 5 \mu \mathrm{m})$ & $\begin{array}{l}10 \% \mathrm{MeCN}, 55 \% \\
\mathrm{MeCN}\end{array}$ & 60 \\
\hline \multicolumn{5}{|l|}{ Qualitative techniques } \\
\hline NanoLC-Orbitrap-MS [10] & $\begin{array}{l}\text { Chlorogenic acid, myricetin-3- } O \text {-glucuronide, } \\
\text { quercetin-3- } O \text {-sambubioside, myricitrin, isoquercitrin, } \\
\text { miquelianin, reynoutrin, astragalin, rutin, } \\
\text { isorhamnetin-3-O-glucuronide, linarin, nicotoflorin }\end{array}$ & $\begin{array}{l}\text { Waters nano Acquity HSS T3 }(100 \mathrm{~mm} \times 100 \mu \mathrm{m} \times \\
\qquad 1.8 \mu \mathrm{m})\end{array}$ & $\begin{array}{l}0.1 \% \mathrm{HCOOH} \\
90 \% \mathrm{CH}_{3} \mathrm{CN}\end{array}$ & 63 \\
\hline UHPLC-DAD-MS/MS [28] & Ellagic acid, agrimoniin & Kinetex C8 $(100 \mathrm{~mm} \times 2.1 \mathrm{~mm} \times 1.7 \mu \mathrm{m})$ & $\begin{array}{l}0.1 \% \mathrm{HCOOH} \\
0.1 \% \mathrm{HCOOH} \text { in } \\
\mathrm{MeCN}\end{array}$ & 35 \\
\hline
\end{tabular}




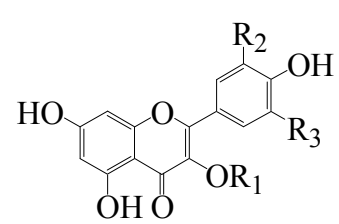

i $\mathrm{R}_{1}=\beta$-D-GlcA $p, \mathrm{R}_{2}=\mathrm{R}_{3}=\mathrm{OH}$

ii $\mathrm{R}_{1}=\left(6^{\prime \prime}-\alpha\right.$-L-Rhap $)-\beta$-D-Glc $p, \mathrm{R}_{2}=\mathrm{OH}, \mathrm{R}_{3}=\mathrm{H}$

iii $\mathrm{R}_{1}=\beta$-D-Glc $p, \mathrm{R}_{2}=\mathrm{OH}, \mathrm{R}_{3}=\mathrm{H}$

iv $\mathrm{R}_{1}=\beta$-D-GlcA $p, \mathrm{R}_{2}=\mathrm{OH}, \mathrm{R}_{3}=\mathrm{H}$

$\mathbf{v} \mathrm{R}_{1}=\beta$-D-Xyl $p, \mathrm{R}_{2}=\mathrm{OH}, \mathrm{R}_{3}=\mathrm{H}$

vi $\mathrm{R}_{1}=\alpha$-L-Rhap, $\mathrm{R}_{2}=\mathrm{OH}, \mathrm{R}_{3}=\mathrm{H}$

vii $\mathrm{R}_{1}=\beta$-D-Glc $p, \mathrm{R}_{2}=\mathrm{OCH}_{3}, \mathrm{R}_{3}=\mathrm{H}$

viii $\mathrm{R}_{1}=\beta$-D-GlcA $p, \mathrm{R}_{2}=\mathrm{OCH}_{3}, \mathrm{R}_{3}=\mathrm{H}$

ix $\mathrm{R}_{1}=\alpha$-L-Rhap, $\mathrm{R}_{2}=\mathrm{R}_{3}=\mathrm{H}$

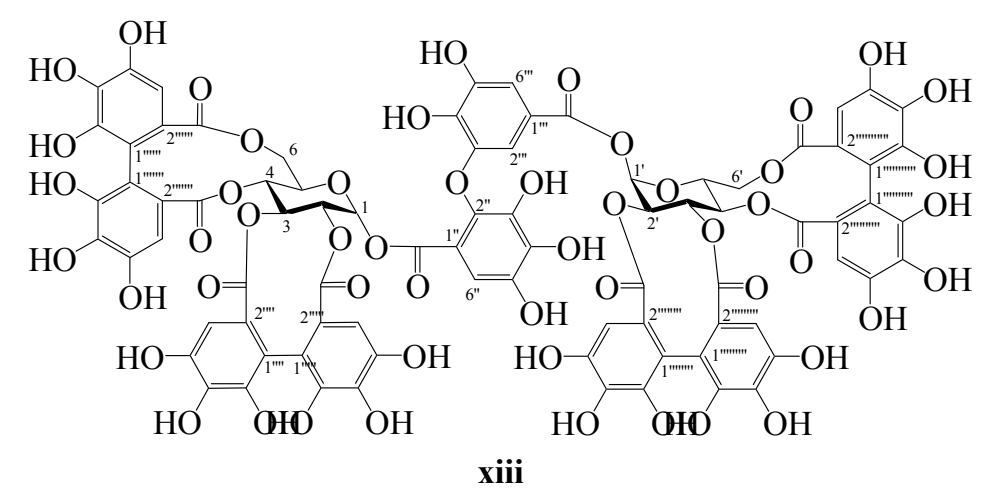

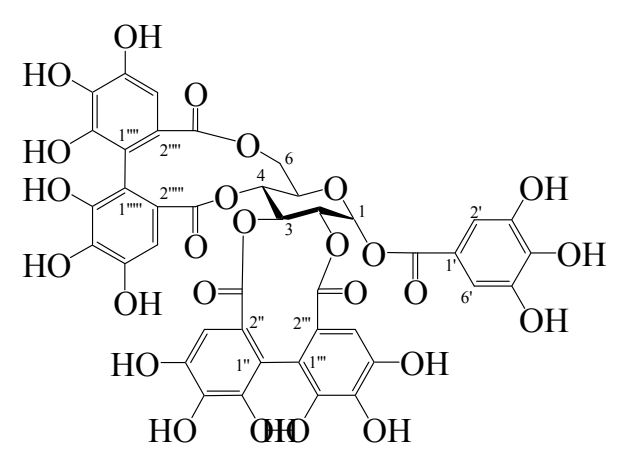

$\mathbf{X}$

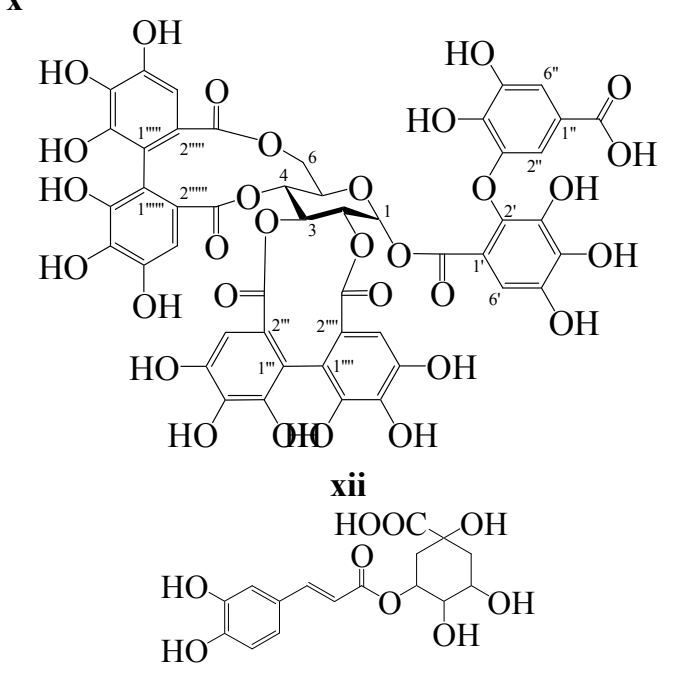

xiv

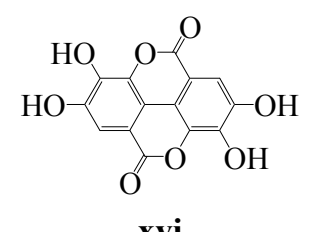

Figure 1. Chemical structures of compounds i-xvii isolated from $P$. anserina herb. $\beta$-D-Glcp- $\beta$-D-glucopyranose; $\beta$-D-GlcAp- $\beta$-Dglucuronopyranose; $\alpha$-L-Rhap $-\alpha$-L-rhamnopyranose; $\beta$-D-Xyl $p-\beta$-D-xylopyranose. 
All isolated flavonoids $\mathbf{i}-\mathbf{i x}$, phenylpropanoids xiv, $\mathbf{x v}$, ellagic acid (xvi) and 2-pyrone-4,6-dicarboxylic acid (xvii) were detected in $P$. anserina herb in early studies of this species $[6,10,12,13]$. Three of the isolated ellagitannins (compounds $\mathbf{x}-\mathbf{x i i}$ ) were detected in $P$. anserina the first time. Previously, compound 10 (pontetillin) was identified as a component of P. kleiniana [31]. Ellagitannin agrimoniin (xiii) isolated from the root of Agrimonia japonica (Miq.) Koidz. [32] was also detected in the herb and roots of some Potentilla species, including P. kleiniana [31], P. anemonefolia, P. centrigrana [32], $P$. erecta [33], P. discolor [34], and $P$. recta [35]. Recently, the presence of agrimoniin was detected in $P$. anserina herb [8]. Compounds xi (agrimonic acid A) and xii (agrimonic acid B) were not detected in Potentilla species before.

\subsection{MC-RP-HPLC-UV Method Development and Validation}

Method development was evaluated with a sample of ethanolic extract of the $P$. anserina herb. Optimum separation of the constituents of $P$. anserina herb was achieved by means of a rather complicated solvent gradient consisting of aqueous $0.2 \mathrm{M} \mathrm{LiClO}_{4}$ in $0.006 \mathrm{M} \mathrm{HClO}_{4}$ and acetonitrile as mobile phases. Replacement of acetonitrine by methanol resulted in the unsatisfactory resolution of adjacent peaks.

Application of isocratic conditions resulted in the elongation of analysis time and bed peak sharpness. Concerning the stationary phase, out of a number of different micro-HPLC columns tested (C-8, C-12, C-16, C-18), the best results were obtained with ProntoSIL-120-5-C18 AQ. It was also discovered that separation was better when column temperature was kept at $35^{\circ} \mathrm{C}$ than lower $\left(20^{\circ}, 30^{\circ} \mathrm{C}\right)$ or higher $\left(40^{\circ}, 45^{\circ} \mathrm{C}\right)$.

The flow rate is an important parameter of a chromatographic process. The application of high flow rates resulted in the reduction of analysis time and more efficient obtainment of data. During the method development, we studied various flow rates from $50 \mu \mathrm{L} \cdot \mathrm{min}^{-1}$ to $1 \mathrm{~mL} \cdot \mathrm{min}^{-1}$. As a result, a $0.6 \mathrm{~mL} \cdot \mathrm{min}^{-1}$ flow rate was chosen as the rate that gave the desired separation and rapid analysis time (5 min).

Preliminary experiments showed that only seven compounds isolated from $P$. anserina were in detectable amounts in extract, including caffeic acid, myricetin-3-O-glucuronide, agrimoniin, ellagic acid, miquelianin, isorhamnetin-3-O-glucuronide, and kaempferol-3-O-rhamnoside. Other identified components are characterized as trace components. According to the absorption maxima of the seven mentioned compounds on the UV-spectra, the monitoring wavelength was set at $270 \mathrm{~nm}$.

Finally, the best separation conditions are the following: column ProntoSIL-120-5-C18 AQ $(1 \mathrm{~mm} \times 60 \mathrm{~mm} \times 5 \mu \mathrm{m})$ eluted with $0.2 \mathrm{M} \mathrm{LiClO}_{4}$ in $0.006 \mathrm{M} \mathrm{HClO}_{4}$ (eluent A) and acetonitrile (eluent B) with a six-step gradient (0-1.25 min $11 \%-18 \% \mathrm{~B}, 1.25-2.25 \mathrm{~min} 18 \% \mathrm{~B}, 2.25-2.5 \mathrm{~min}$ $18 \%-20 \%$ B, 2.5-3.0 min 20\%-25\% B, 3.0-4.0 min 25\% B, 4.0-5.0 min 25\%-100\% B) with flow rate $0.6 \mathrm{~mL} \cdot \mathrm{min}^{-1}$ and maintained at $35{ }^{\circ} \mathrm{C}$. Representative chromatograms of standard solution and $P$. anserina extract are shown in Figure 2. 


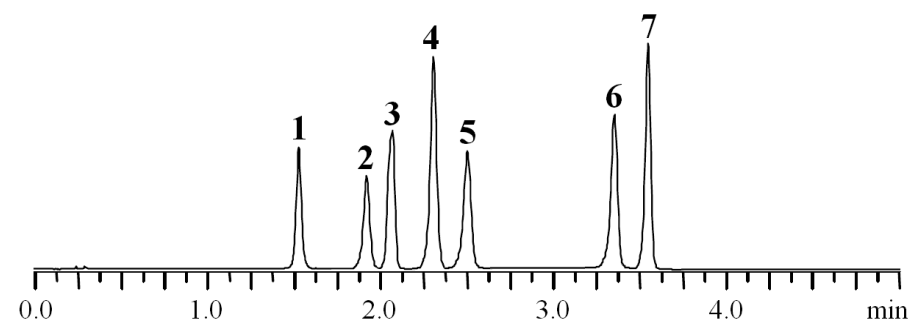

(a)

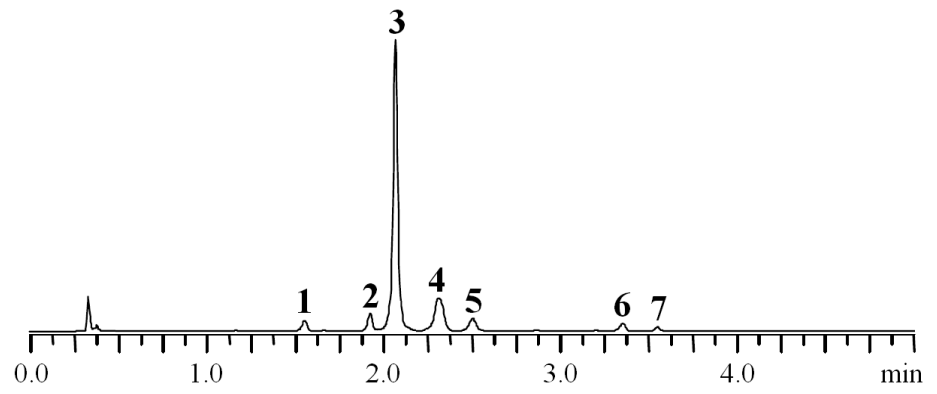

(b)

Figure 2. MC-RP-HPLC-UV chromatograms of standard mixture (a) and P. anserina extract (b) detected at $270 \mathrm{~nm}$. 1. caffeic acid; 2. myricetin-3-O-glucuronide; 3. agrimoniin; 4. ellagic acid; 5. miquelianin; 6. isorhamnetin-3-O-glucuronide; 7. kaempferol-3- $O$-rhamnoside.

The proposed microcolumn RP-HPLC-UV method was validated in terms of linearity, precision, repeatability, recovery, and solution stability and robustness. The results of method validation are listed in Tables 2 and 3.

Table 2. Linear regression data, LOD and LOQ of seven compounds from P. anserina.

\begin{tabular}{ccccccc}
\hline Compound & Regression Equation & $\boldsymbol{r}^{\mathbf{2}}$ & $\boldsymbol{S}_{\boldsymbol{Y} X}$ & $\begin{array}{c}\text { Linear Range, } \\
\boldsymbol{\mu g} / \mathbf{m L}\end{array}$ & $\begin{array}{c}\mathbf{L O D}, \\
\boldsymbol{\mu g} / \mathbf{m L}\end{array}$ & $\begin{array}{c}\mathbf{L O Q}, \\
\boldsymbol{\mu g} / \mathbf{m L}\end{array}$ \\
\hline Caffeic acid & $Y=0.0203 \times X-0.0073$ & 0.9999 & $0.28 \cdot 10^{-2}$ & $2-1500$ & 0.46 & 1.38 \\
Myricetin-3-O-glucuronide & $Y=0.0194 \times X-0.0376$ & 0.9999 & $1.14 \cdot 10^{-2}$ & $10-2000$ & 1.94 & 5.88 \\
Agrimoniin & $Y=0.0307 \times X-0.0416$ & 0.9999 & $1.22 \cdot 10^{-2}$ & $5-2500$ & 1.31 & 3.97 \\
Ellagic acid & $Y=0.0647 \times X-0.0803$ & 0.9998 & $1.36 \cdot 10^{-2}$ & $2.5-1800$ & 0.69 & 2.10 \\
Miquelianin & $Y=0.0285 \times X-0.0363$ & 0.9999 & $0.78 \cdot 10^{-2}$ & $5-1500$ & 0.90 & 2.74 \\
Isorhamnetin-3- $O$-glucuronide & $Y=0.0328 \times X-0.0190$ & 0.9999 & $0.88 \cdot 10^{-2}$ & $5-1500$ & 0.89 & 2.68 \\
Kaempferol-3- $O$-rhamnoside & $Y=0.0402 \times X-0.0119$ & 0.9999 & $0.26 \cdot 10^{-2}$ & $2-1000$ & 0.21 & 0.65 \\
\hline
\end{tabular}

Table 3. Precision and repeatability data of seven compounds from P. anserina.

\begin{tabular}{ccccc}
\hline Compound & Repeatability, \% & Variability, \% & Intra-Day Precision, \% & Inter-Day Precision, \% \\
\hline Caffeic acid & 1.03 & 2.04 & 1.35 & 1.57 \\
Myricetin-3-O-glucuronide & 1.49 & 1.57 & 1.93 & 2.14 \\
Agrimoniin & 2.02 & 1.93 & 2.20 & 2.57 \\
Ellagic acid & 2.17 & 2.63 & 2.34 & 2.72 \\
Miquelianin & 1.56 & 1.11 & 1.53 & 2.11 \\
Isorhamnetin-3-O-glucuronide & 0.92 & 0.71 & 1.69 & 2.09 \\
Kaempferol-3- $O$-rhamnoside & 0.67 & 0.52 & 1.43 & 1.87 \\
\hline
\end{tabular}


A linear relationship was obtained between a response (peak area) and the amount of phenolic compounds in the ranges $2-1500,10-2000,5-3000,2.5-1800,5-1500,5-1500$, and $2-1000 \mu \mathrm{g} / \mathrm{mL}$ for caffeic acid, myricetin-3-O-glucuronide, agrimoniin, ellagic acid, miquelianin, isorhamnetin-3-Oglucuronide, and kaempferol-3-O-rhamnoside, respectively. The correlation coefficients were 0.9999 for caffeic acid, myricetin-3-O-glucuronide, agrimoniin, miquelianin, isorhamnetin-3-O-glucuronide, and kaempferol-3-O-rhamnoside, and 0.9998 for ellagic acid. Limits of detection (LOD) of caffeic acid, myricetin-3-O-glucuronide, agrimoniin, ellagic acid, miquelianin, isorhamnetin-3-O-glucuronide, and kaempferol-3-O-rhamnoside were $0.46,1.94,1.31,0.69,0.90$, and $0.89 \mu \mathrm{g} / \mathrm{mL}$, respectively.

Intra- and inter-day variations, which are presented in terms of percent relative standard deviation (\%RSD) of the analyte's peak area and variability were chosen to determine the precision of the developed method. For intra-day variability test, the calibration sample solutions were analysed for five replicates within one day, while the solutions were examined in duplicates for three consecutive days for inter-day variability tests. Values of intra- and inter-day precision were $1.35-2.34$ and $1.57 \%-2.72 \%$, respectively. The repeatability of the method was $0.67 \%-2.17 \%$, while the variability was $0.52 \%-2.63 \%$.

The recovery was determined by the standard addition method. Seven phenolic compounds were spiked into the samples, and then extracted, processed, and quantified in accordance with the established procedures. Each sample was analyzed five times to determine the mean content $(\mu \mathrm{g} / \mathrm{mL})$. The RSD value was calculated as a measurement of method repeatability. The results are presented in Table 4.

Table 4. Recoveries of seven compounds in P. anserina.

\begin{tabular}{|c|c|c|c|c|c|}
\hline Compound & Original Content, $\mu \mathrm{g} / \mathrm{mL}$ & Spiked, $\mu \mathrm{g} / \mathrm{mL}$ & Detected, $\mu \mathrm{g} / \mathrm{mL}$ & Recovery, \% & RSD, \% \\
\hline \multirow[t]{3}{*}{ Caffeic acid } & 106.55 & 60 & 167.42 & 100.52 & 1.16 \\
\hline & & 90 & 194.16 & 98.78 & 1.31 \\
\hline & & 120 & 221.02 & 97.56 & 1.69 \\
\hline \multirow[t]{3}{*}{ Myricetin-3-O-glucuronide } & 316.56 & 160 & 484.37 & 101.64 & 2.02 \\
\hline & & 240 & 553.28 & 99.41 & 1.63 \\
\hline & & 320 & 623.90 & 98.01 & 1.84 \\
\hline \multirow[t]{3}{*}{ Agrimoniin } & 1026.34 & 500 & 1542.37 & 101.05 & 1.63 \\
\hline & & 750 & 1806.22 & 101.68 & 1.92 \\
\hline & & 1000 & 2074.58 & 102.38 & 2.14 \\
\hline \multirow[t]{3}{*}{ Ellagic acid } & 216.03 & 110 & 320.62 & 98.34 & 1.12 \\
\hline & & 165 & 377.75 & 99.14 & 1.67 \\
\hline & & 220 & 441.43 & 101.24 & 1.90 \\
\hline \multirow[t]{3}{*}{ Miquelianin } & 165.34 & 80 & 239.26 & 97.52 & 1.31 \\
\hline & & 120 & 280.03 & 98.14 & 2.10 \\
\hline & & 160 & 328.33 & 100.92 & 2.16 \\
\hline \multirow[t]{3}{*}{ Isorhamnetin-3-O-glucuronide } & 69.77 & 40 & 107.86 & 98.26 & 1.09 \\
\hline & & 60 & 126.07 & 97.15 & 1.52 \\
\hline & & 80 & 148.53 & 99.17 & 1.16 \\
\hline \multirow[t]{3}{*}{ Kaempferol-3-O-rhamnoside } & 20.94 & 10 & 31.44 & 101.62 & 1.34 \\
\hline & & 15 & 35.72 & 99.39 & 0.92 \\
\hline & & 20 & 41.73 & 101.93 & 1.27 \\
\hline
\end{tabular}


The stability of standard and sample solutions was determined by monitoring the peak area of standard mixture solutions and retention time with sample solutions over a period of one day. The results showed that the peak area and retention time of each analyte were almost unchanged. The concentration of substances after each storage period was related to the initial analyte concentrations of freshly prepared samples. Samples were stable within the acceptable limits of accuracy and precision at least in $24 \mathrm{~h}$.

The results of method validation of qualitative and quantitative analysis showed that the microcolumn RP-HPLC-UV method was precise, recovery and accurate enough for the simultaneous quantitative and qualitative evaluation of seven phenolic compounds in P. anserina herb.

\subsection{Optimisation of Extraction Procedure of the Main Phenolic Compounds from the P. anserina Herb}

Various solvents, extraction methods, temperatures, and times were evaluated to obtain the best extraction efficiency. The results of the determination of the best extraction type revealed that sonification was better than refluxing and stirring, so the subsequent experiments were carried out with sonification.

According to the literature data there is no "common" solvent for extraction of $P$. anserina phenolic compounds; separate authors used 70\% acetone [13], 30\%-100\% methanol [7,8], 70\% ethanol [10], and water [28]. For this reason, different media, including conventional solvents as water and alcohols, as well as uncommon solvents like ketones, ethers, and DMSO, were screened (Table 5). The results achieved for the aqueous extract showed the highest content of caffeic acid $(152.68 \mu \mathrm{g} / \mathrm{mL})$; the concentration of flavonoids, agrimoniin, and ellagic acid is much lower than that of the methanol extract. Ethanol extract is characterized by the intermediate values of the concentrations of all compounds except ellagic acid, the concentration of which is lower than in water extraction $(7.89 \mu \mathrm{g} / \mathrm{mL})$. The values of the total content of phenolics were $639.27,1123.04$, and $585.60 \mu \mathrm{g} / \mathrm{mL}$ in water, methanol, and ethanol extract, respectively. Application of the $n$-propanol and iso-propanol did not allow for the obtaining of the extacts with higher content; total identified compounds content in $n$-propanol and iso-propanol extracts were 122.62 and $26.41 \mu \mathrm{g} / \mathrm{mL}$, respectively. The extraction power of other solvents decreased sequentially in line: $n$-propanol $>>$ iso-propanol $\approx$ acetone $>$ ethylacetate $>$ methylethylketone $>$ acetonitrile. The latter solvent is characterized by traced ability to extraction of $P$. anserina phenolics.

The use of polar aprotic solvent DMSO allows for the preparation of extract with the highest total phenolic content, $1806.23 \mu \mathrm{g} / \mathrm{mL}$. However, the content of caffeic acid $(135.61 \mu \mathrm{g} / \mathrm{mL})$ was lower than in water extract. In a further step, we analyzed a quantitative compositions of extracts prepared on water-containing solvent at a 50\% level of water content (just water miscible solvents were used). As a result, a significant increase of phenolic content was observed for all solvents. The extraction power of $50 \%$ solvent presented in the following manner: acetone $>$ DMSO $>$ acetonitrile $>n$-propanol $>$ ethanol $>$ iso-propanol $>$ methanol. Maximal content of all analyzing compounds was detected in acetone containing media that were determined as perspective solvents and examined in further experiments.

To obtain more specific information about optimal acetone concentrations, the various dilutions of acetone were used as solvents for extraction of $P$. anserina phenolics. When the concentration of acetone increased from $0 \%$ to $60 \%$, the yield of phenols increased significantly, reaching a maximum value, $2949.76 \mu \mathrm{g} / \mathrm{mL}$, at $60 \%$ acetone. Then, an obvious decrease of all compounds content with further 
increases of the acetone concentration from $60 \%$ to $90 \%$ was observed. Thus, $60 \%$ acetone is an appropriate solvent for the extraction of $P$. anserina phenolics.

Table 5. Content of seven compounds in P. anserina extracts, $\mu \mathrm{g} / \mathrm{mL} *$.

\begin{tabular}{|c|c|c|c|c|c|c|c|c|}
\hline \multirow{2}{*}{ Solvent } & \multicolumn{8}{|c|}{ Compound $* *$} \\
\hline & 1 & 2 & 3 & 4 & 5 & 6 & 7 & Total \\
\hline \multicolumn{9}{|c|}{$100 \%$ solvent } \\
\hline Water & 152.68 & 71.36 & 281.19 & 80.07 & 23.10 & 28.59 & 2.28 & 639.27 \\
\hline Methanol & 44.36 & 92.54 & 760.95 & 106.97 & 61.39 & 49.06 & 7.77 & 1123.04 \\
\hline Ethanol & 133.65 & 54.00 & 304.12 & 7.89 & 35.01 & 45.30 & 5.63 & 585.60 \\
\hline$n$-Propanol & 6.11 & 65.05 & 24.43 & 11.91 & 7.09 & 8.03 & $\operatorname{tr}$. & 122.62 \\
\hline iso-Propanol & tr. & 8.26 & 2.47 & 6.72 & 3.64 & 5.32 & tr. & 26.41 \\
\hline Acetone & tr. & 2.50 & 11.82 & 6.39 & tr. & tr. & 4.11 & 24.82 \\
\hline Methylethylketone & tr. & tr. & 5.63 & tr. & tr. & 2.31 & $\operatorname{tr}$. & 7.94 \\
\hline Acetonitrile & tr. & n.d. & tr. & tr. & tr. & tr. & n.d. & tr. \\
\hline Ethylacetate & $\operatorname{tr}$. & 6.88 & 4.11 & tr. & tr. & $\operatorname{tr}$. & tr. & 10.99 \\
\hline DMSO & 135.61 & 243.29 & 1004.63 & 189.40 & 140.40 & 74.78 & 18.12 & 1806.23 \\
\hline \multicolumn{9}{|c|}{$50 \%$ solvent } \\
\hline Methanol & 150.87 & 221.16 & 901.55 & 152.78 & 135.84 & 67.45 & 21.56 & 1651.21 \\
\hline Ethanol & 157.35 & 230.26 & 1040.53 & 183.61 & 135.12 & 67.00 & 23.76 & 1837.63 \\
\hline$n$-Propanol & 123.16 & 260.76 & 1153.46 & 204.15 & 160.15 & 79.22 & 25.34 & 2006.24 \\
\hline iso-Propanol & 185.43 & 216.12 & 927.21 & 194.99 & 144.03 & 72.87 & 25.14 & 1765.79 \\
\hline Acetone & 189.26 & 264.17 & 1713.24 & 210.76 & 161.31 & 79.82 & 25.52 & 2644.08 \\
\hline Acetonitrile & 142.40 & 247.72 & 1315.63 & 191.51 & 139.75 & 74.78 & 21.50 & 2133.29 \\
\hline DMSO & 180.70 & 247.94 & 1611.49 & 187.19 & 143.78 & 62.52 & 23.97 & 2457.59 \\
\hline \multicolumn{9}{|c|}{ Acetone. Various concentrations } \\
\hline $20 \%$ & 180.33 & 218.78 & 887.82 & 148.09 & 129.54 & 60.93 & 21.11 & 1646.60 \\
\hline $30 \%$ & 183.55 & 224.61 & 1127.97 & 173.80 & 131.63 & 61.14 & 22.39 & 1925.09 \\
\hline $40 \%$ & 185.26 & 237.73 & 1578.04 & 202.97 & 154.53 & 74.04 & 25.61 & 2458.18 \\
\hline $60 \%$ & 190.49 & 296.93 & 1953.69 & 229.07 & 169.21 & 81.97 & 28.40 & 2949.76 \\
\hline $70 \%$ & 114.05 & 252.02 & 1824.03 & 212.02 & 123.24 & 48.89 & 25.09 & 2599.34 \\
\hline $80 \%$ & 93.42 & 149.39 & 1821.94 & 180.95 & 86.12 & 28.69 & 19.44 & 2379.95 \\
\hline $90 \%$ & 21.16 & 41.16 & 126.11 & 56.09 & 10.57 & 12.10 & 5.63 & 272.82 \\
\hline
\end{tabular}

* Extraction conditions: liquid-to-solid ratio $1: 25$, extraction temperature $40{ }^{\circ} \mathrm{C}$, extraction time $30 \mathrm{~min}$; ** 1. caffeic acid; 2. myricetin-3-O-glucuronide; 3. agrimoniin; 4. ellagic acid; 5. miquelianin; 6. isorhamnetin-3-O-glucuronide; 7. kaempferol-3-O-rhamnoside.

To determine the effect of the liquid-to-solid ratio on extraction yield, experiments were carried out at a ratio ranging between 1:5 and 1:100. As shown in Figure 3a, the extraction yield initially increased when the ratio increased from 1:5 to 1:40, and then remained fairly constant for all compounds except agrimoniin. The further increasing of the liquid-to-solid ratio resulted in the decreasing of agrimoniin content (from $51.31 \mathrm{mg} \cdot \mathrm{g}^{-1}$ at $1: 40$ to $49.81 \mathrm{mg} \cdot \mathrm{g}^{-1}$ at $1: 100$ ). Therefore, the liquid-to-solid ratio of 1:40 was chosen for further optimization studies. 


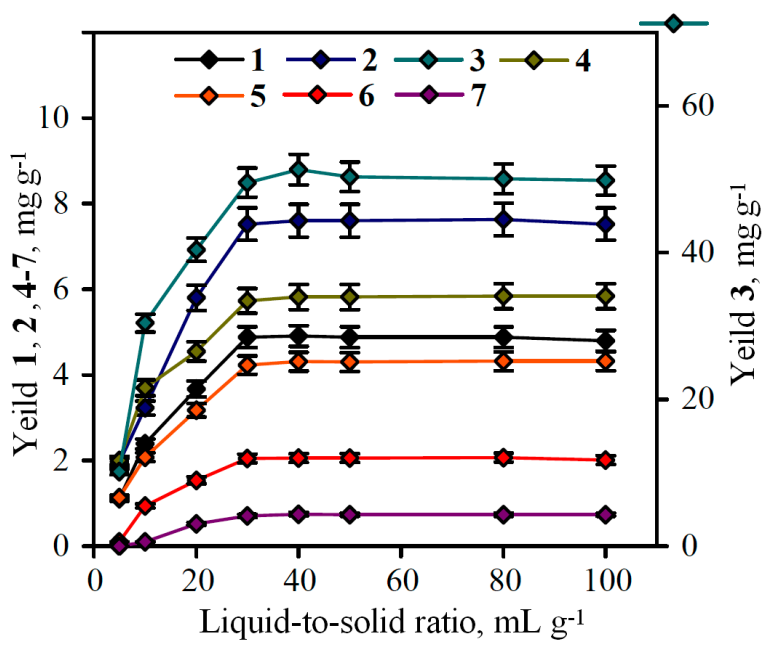

(a)

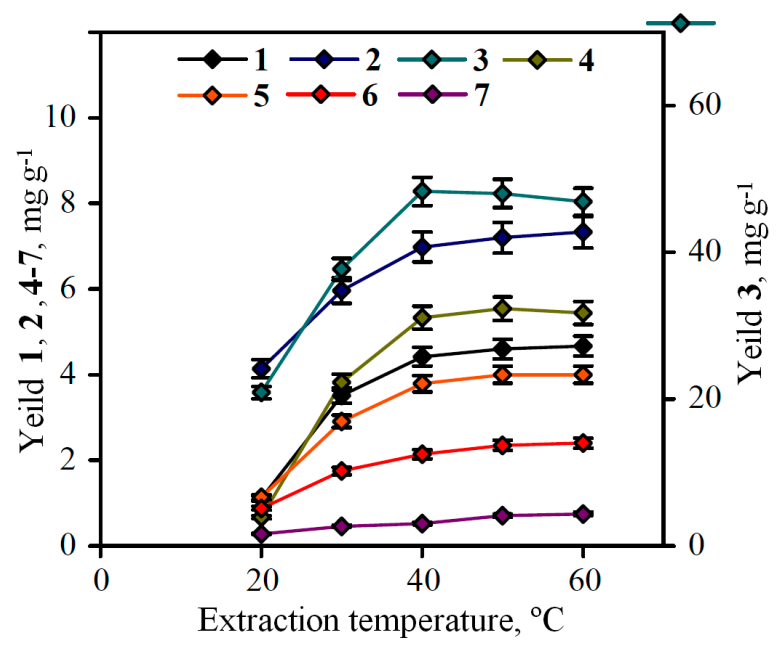

(b)

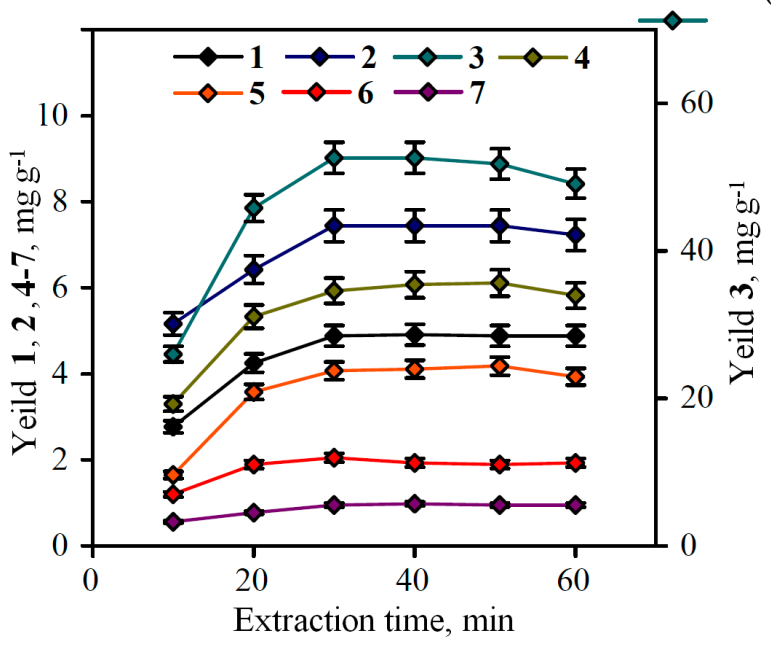

(c)

Figure 3. Effects of extraction parameters on the phenolic compounds yield: (a) effect of liquid-to-solid ratio; (b) effect of extraction temperature; (c) effect of extraction time. 1. caffeic acid; 2. myricetin-3-O-glucuronide; 3. agrimoniin; 4. ellagic acid; 5. miquelianin; 6. isorhamnetin-3-O-glucuronide; 7. kaempferol-3-O-rhamnoside.

The influence of extraction temperature on the efficacy of extraction was investigated. Samples of $P$. anserina were sonificated with $60 \%$ acetone in liquid-to-solid ratio $1: 40$ at $20-60{ }^{\circ} \mathrm{C}$. The limitation of temperature interval by $60{ }^{\circ} \mathrm{C}$ point induced by the boiling point of $60 \%$ acetone which is approximately $62-65{ }^{\circ} \mathrm{C}$. The results obtained were variable for different compounds (Figure $3 b$ ).

The maximal agrimoniin content was detected in $40{ }^{\circ} \mathrm{C}$-extract, $50.32 \pm 1.18 \mathrm{mg} \cdot \mathrm{g}^{-1}$; then we observed the reduction of agrimoniin content up to $46.74 \pm 1.07 \mathrm{mg} \cdot \mathrm{g}^{-1}$ at $60{ }^{\circ} \mathrm{C}$. For some flavonoids (myricetin-3-O-glucuronide, isorhamnetin-3-O-glucuronide, kaempferol-3- $O$-rhamnoside) in a $40-60{ }^{\circ} \mathrm{C}$ interval, the increasing of extraction temperature up to $60^{\circ} \mathrm{C}$ resulted in the rising of the concentration (for myricetin-3-O-glucuronide from $7.02 \mathrm{mg} \cdot \mathrm{g}^{-1}$ to $7.23 \mathrm{mg} \cdot \mathrm{g}^{-1}$; for isorhamnetin-3-O-glucuronide from $2.14 \mathrm{mg} \cdot \mathrm{g}^{-1}$ to $2.21 \mathrm{mg} \cdot \mathrm{g}^{-1}$; for kaempferol-3-O-rhamnoside from $0.52 \mathrm{mg} \cdot \mathrm{g}^{-1}$ to $0.54 \mathrm{mg} \cdot \mathrm{g}^{-1}$ ). The reason for these changes is the greater stability of flavonoids to the influence of temperature factor as opposed to ellagitannins. The differences of concentration in $40{ }^{\circ} \mathrm{C}$ - and $60{ }^{\circ} \mathrm{C}$-extracts for the mentioned compounds are $-3.58 \mathrm{mg} \cdot \mathrm{g}^{-1},+0.21 \mathrm{mg} \cdot \mathrm{g}^{-1},+0.07 \mathrm{mg} \cdot \mathrm{g}^{-1}$, and $+0.02 \mathrm{mg} \cdot \mathrm{g}^{-1}$, 
respectively, for agrimoniin, myricetin-3-O-glucuronide, isorhamnetin-3-O-glucuronide, and kaempferol-3-O-rhamnoside. In consideration of the more expressed value of concentration lost for agrimoniin, we decided to choose $40{ }^{\circ} \mathrm{C}$ as an optimal temperature point.

In order to obtain the maximum yield of phenolic compounds from $P$. anserina, sonification was performed with $60 \%$ acetone in the liquid-to-solid ratio $1: 40$ at $40{ }^{\circ} \mathrm{C}$ and at six extraction times from 10 to $60 \mathrm{~min}$ (Figure $3 \mathrm{c}$ ). It was revealed that the period $30 \mathrm{~min}$ of extraction time favours the phenolic compounds' production. Further increasing the extraction time did not show a significant increase in the flavonoid and phenolic acid content. Moreover, the decreasing of agrimoniin content was observed after $30 \mathrm{~min}$ of extraction. Therefore, $30 \mathrm{~min}$ was chosen as the extraction time in subsequent experiments.

\subsection{Phenolic Content in P. anserina Herb and Some Preparations}

The developed method was successfully applied to the analysis of 12 batches of the $P$. anserina herb collected from three Siberian regions (Yakutia, Buryatia, Irkutsk) and two commercial samples. The desired components in $P$. anserina herb were identified by comparing both the retention times and UV spectra of phenolic compounds with those of the reference standards. To check the peak purity, the eluates were monitored at 200-400 $\mathrm{nm}$ in upslope, apex, and downslope of each peak, and the resulting three spectra were normalised and superimposed. A peak was considered pure when there was an exact coincidence among three spectra [36]. The results showed the presence of seven required compounds in all analyzed batches of $P$. anserina herb (Table 6). The peak's purity was satisfactory for quantitative analysis of samples.

Table 6. Content of seven compounds in P. anserina herb, $\mathrm{mg} \cdot \mathrm{g}^{-1}$.

\begin{tabular}{|c|c|c|c|c|c|c|c|c|}
\hline \multirow{2}{*}{ Batch No } & \multicolumn{8}{|c|}{ Compound * } \\
\hline & 1 & 2 & 3 & 4 & 5 & 6 & 7 & Total \\
\hline PA-Y-01(2013) & $2.14 \pm 0.05$ & $5.20 \pm 0.09$ & $53.12 \pm 1.12$ & $4.83 \pm 0.12$ & $3.15 \pm 0.07$ & $1.18 \pm 0.03$ & $0.92 \pm 0.02$ & 70.54 \\
\hline PA-Y-02(2013) & $3.18 \pm 0.07$ & $6.19 \pm 0.11$ & $57.29 \pm 1.26$ & $3.02 \pm 0.07$ & $4.18 \pm 0.09$ & $1.37 \pm 0.03$ & $1.52 \pm 0.04$ & 76.75 \\
\hline PA-Y-03(2014) & $4.12 \pm 0.09$ & $7.93 \pm 0.15$ & $51.14 \pm 1.02$ & $3.12 \pm 0.06$ & $3.07 \pm 0.07$ & $2.69 \pm 0.06$ & $1.93 \pm 0.04$ & 74.00 \\
\hline PA-Y-04(2014) & $4.76 \pm 0.10$ & $7.42 \pm 0.14$ & $48.83 \pm 1.07$ & $5.77 \pm 0.14$ & $4.23 \pm 0.09$ & $2.05 \pm 0.05$ & $0.71 \pm 0.02$ & 73.77 \\
\hline PA-B-05(2012) & $4.97 \pm 0.11$ & $8.63 \pm 0.16$ & $37.19 \pm 0.81$ & $3.21 \pm 0.08$ & $5.93 \pm 0.12$ & $3.37 \pm 0.07$ & $2.41 \pm 0.06$ & 65.71 \\
\hline PA-B-06(2013) & $5.39 \pm 0.11$ & $9.10 \pm 0.18$ & $30.06 \pm 0.72$ & $2.93 \pm 0.07$ & $6.29 \pm 0.15$ & $3.30 \pm 0.07$ & $1.98 \pm 0.04$ & 59.05 \\
\hline PA-B-07(2014) & $5.64 \pm 0.12$ & $8.54 \pm 0.17$ & $40.14 \pm 0.84$ & $2.44 \pm 0.06$ & $6.54 \pm 0.16$ & $2.97 \pm 0.06$ & $2.52 \pm 0.05$ & 68.79 \\
\hline PA-B-08(2014) & $5.97 \pm 0.14$ & $8.29 \pm 0.16$ & $22.17 \pm 0.42$ & $1.92 \pm 0.04$ & $6.97 \pm 0.19$ & $3.72 \pm 0.08$ & $2.67 \pm 0.05$ & 51.71 \\
\hline PA-I-09(2012) & $6.18 \pm 0.12$ & $8.90 \pm 0.17$ & $20.69 \pm 0.46$ & $1.84 \pm 0.04$ & $6.38 \pm 0.14$ & $4.69 \pm 0.09$ & $3.74 \pm 0.08$ & 52.42 \\
\hline PA-I-10(2013) & $5.32 \pm 0.11$ & $9.21 \pm 0.17$ & $18.33 \pm 0.38$ & $1.24 \pm 0.03$ & $7.52 \pm 0.18$ & $5.27 \pm 0.12$ & $3.11 \pm 0.07$ & 50.00 \\
\hline PA-I-11(2014) & $5.18 \pm 0.10$ & $10.36 \pm 0.21$ & $22.94 \pm 0.55$ & $0.97 \pm 0.02$ & $8.12 \pm 0.19$ & $5.22 \pm 0.12$ & $3.62 \pm 0.08$ & 56.41 \\
\hline PA-I-12(2014) & $6.04 \pm 0.14$ & $6.52 \pm 0.12$ & $25.11 \pm 0.59$ & $1.25 \pm 0.03$ & $8.04 \pm 0.17$ & $4.37 \pm 0.10$ & $3.68 \pm 0.08$ & 55.01 \\
\hline PA-C-13(2014) & $3.18 \pm 0.05$ & $7.52 \pm 0.17$ & $32.57 \pm 0.68$ & $2.61 \pm 0.06$ & $3.36 \pm 0.07$ & $2.10 \pm 0.05$ & $1.37 \pm 0.03$ & 52.71 \\
\hline PA-C-14(2014) & $5.22 \pm 0.10$ & $4.18 \pm 0.08$ & $41.17 \pm 0.82$ & $3.79 \pm 0.10$ & $3.14 \pm 0.05$ & $1.94 \pm 0.04$ & $0.62 \pm 0.01$ & 60.06 \\
\hline
\end{tabular}

* 1. caffeic acid; 2. myricetin-3-O-glucuronide; 3. agrimoniin; 4. ellagic acid; 5. miquelianin; 6. isorhamnetin-3-O-glucuronide; 7. kaempferol-3-O-rhamnoside.

The data obtained demonstrated the fact of agrimoniin domination in all samples of $P$. anserina herb in a wide range of concentrations, $18.33-57.29 \mathrm{mg} \cdot \mathrm{g}^{-1}$. The variation of flavonoid and phenolic acid 
content was as follows: caffeic acid $2.14-6.18 \mathrm{mg} \cdot \mathrm{g}^{-1}$, myricetin-3-O-glucuronide $4.18-10.36 \mathrm{mg} \cdot \mathrm{g}^{-1}$, ellagic acid $0.97-5.77 \mathrm{mg} \cdot \mathrm{g}^{-1}$, miquelianin $3.07-8.12 \mathrm{mg} \cdot \mathrm{g}^{-1}$, isorhamnetin-3-O-glucuronide $1.18-5.27 \mathrm{mg} \cdot \mathrm{g}^{-1}$, and kaempferol-3-O-rhamnoside $0.62-3.74 \mathrm{mg} \cdot \mathrm{g}^{-1}$. The minimal value of the total phenolic content was observed in the Irkutsk sample PA-I-10(2013), $50.00 \mathrm{mg} \cdot \mathrm{g}^{-1}$, and the maximal content was marked in the Yakutia sample PA-Y-02(2013), $76.75 \mathrm{mg} \cdot \mathrm{g}^{-1}$.

It should be noted that the samples of $P$. anserina collected in three Siberia regions were characterized by different abilities to accumulate the phenolic compounds (Figure 4). The Yakutian populations contained high concentrations of agrimoniin $\left(48.83-57.29 \mathrm{mg} \cdot \mathrm{g}^{-1}\right)$ and low concentrations of flavonoids $\left(10.45-15.62 \mathrm{mg} \cdot \mathrm{g}^{-1}\right)$. An opposite character of accumulation was observed in the Irkutsk populations, viz. low agrimoniin content $\left(18.33-25.11 \mathrm{mg} \cdot \mathrm{g}^{-1}\right)$ and high flavonoid content (22.61-27.32 $\left.\mathrm{mg} \cdot \mathrm{g}^{-1}\right)$. The plant populations growing in Buryatia occupied an intermediate position (agrimoniin 22.17-40.14 $\mathrm{mg} \cdot \mathrm{g}^{-1}$; flavonoids $20.34-21.65 \mathrm{mg} \cdot \mathrm{g}^{-1}$ ). Early data about the chemical profile of the $P$. anserina herb growing in different regions indicate a high content of tannins in Polish populations $(1.75 \%-2.26 \%)$ [8] and a low content of flavonoids $(0.48 \%-0.60 \%)$, respectively [7]. P. anserina of German origin were characterized as a high-flavonoid containing population $(>1 \%)$, while in the Ukrainian samples the content of flavonoids were on the lowest level (0.35\%) [37]. According to the German Drug Codex Supplement to Pharmacopoeia (DAC), the tannin content in $P$. anserina herb should not be less than 2\% [38]. Therefore, Polish and Siberian populations (except some Irkutsk batches) of $P$. anserina may be regarded as satisfactory.

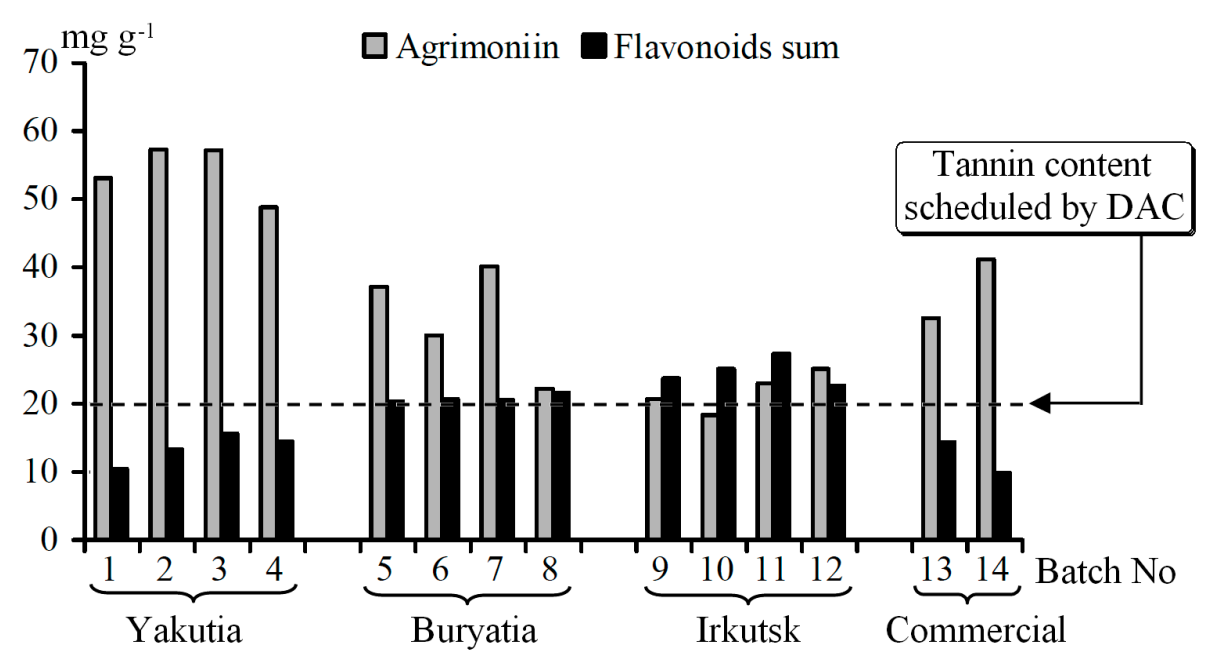

Figure 4. Content of agrimoniin and flavonoids sum in $P$. anserina herb batches.

Chromatographic analysis of flowers, leaves, and stems of $P$. anserina showed that none of the investigated plant parts contained additional phenolic constituents; only variations in the content of the seven analyzed compounds were observed (Table 7). The highest content of agrimoniin was detected in leaves $\left(61.27 \mathrm{mg} \cdot \mathrm{g}^{-1}\right)$, followed by stems $\left(25.03 \mathrm{mg} \cdot \mathrm{g}^{-1}\right)$ and flowers $\left(21.98 \mathrm{mg} \cdot \mathrm{g}^{-1}\right)$. The distribution of phenolic acids and flavonoids was different; the maximal concentrations were in flowers and the minimal ones in stems. The tannin:flavonoid ratio in the flowers, leaves, and stems was $\sim 1: 1,4.3: 1$, and 3.6:1, respectively. 
Table 7. Content of seven compounds in P. anserina organs, $\mathrm{mg} \cdot \mathrm{g}^{-1} *$.

\begin{tabular}{cccc}
\hline Compound & Flowers & Leaves & Stems \\
\hline Caffeic acid & $8.89 \pm 0.19$ & $7.63 \pm 0.15$ & $0.82 \pm 0.02$ \\
Myricetin-3-O-glucuronide & $10.99 \pm 0.21$ & $7.72 \pm 0.14$ & $3.50 \pm 0.07$ \\
Agrimoniin & $21.98 \pm 0.39$ & $61.27 \pm 1.16$ & $25.03 \pm 0.47$ \\
Ellagic acid & $5.93 \pm 0.15$ & $5.62 \pm 0.14$ & $4.50 \pm 0.10$ \\
Miquelianin & $6.51 \pm 0.12$ & $3.27 \pm 0.06$ & $2.06 \pm 0.04$ \\
Isorhamnetin-3- $O$-glucuronide & $2.75 \pm 0.05$ & $2.67 \pm 0.05$ & $1.17 \pm 0.02$ \\
Kaempferol-3- $O$-rhamnoside & $1.56 \pm 0.04$ & $0.45 \pm 0.01$ & $0.31 \pm 0.01$ \\
Total content & 58.61 & 88.63 & 37.39 \\
\hline
\end{tabular}

* sample PA-Y-02(2013).

The previously mentioned differences in phenolic compounds content in P. anserina collected in various countries might result from the environmental effects, and the extraction conditions, as well as different development stadium of the investigated plants or the different ratios of flowers, leaves, and stems in the analyzed samples. Given the widespread use of preparations from $P$. anserina in therapeutic practice, we studied the quantitative content of phenolic compounds in five medical forms, including ethanol containing forms (liquid extract and tincture), decoction, and infusion as frequently applied home-made forms and dry extract used for tablet and pill manufacturing. The qualitative composition of the analyzed preparations from $P$. anserina was similar to those of native plant material. This fact indicates the safety of the componential profile of the analyzed preparations within the manufacturing process.

The most enriched liquid formulation was liquid extract characterized by $5.86 \mathrm{mg} / \mathrm{mL}$ of total phenolic content (Table 8). Tincture, decoction, and infusion are dosage forms prepared by low-extensive technology that affects the quality of the resulting product. The total content of agrimoniin in infusion as the most depleted form was $0.11 \mathrm{mg} / \mathrm{mL}$, which was almost 23 times smaller than that on the liquid extract $(2.34 \mathrm{mg} / \mathrm{mL})$. The differences in total flavonoid content between infusion and liquid extract were less pronounced: $0.66 \mathrm{mg} / \mathrm{mL}$ and $2.05 \mathrm{mg} / \mathrm{mL}$, respectively. Tincture and decoction are the medical preparations with intermediate quantitative parameters.

Table 8. Content of seven compounds in P. anserina preparations.

\begin{tabular}{cccccc}
\hline Compound & $\begin{array}{c}\text { Liquid Extract, } \\
\mathbf{\mu g} / \mathbf{m L}\end{array}$ & $\begin{array}{c}\text { Tincture, } \\
\mathbf{\mu g} / \mathbf{m L}\end{array}$ & $\begin{array}{c}\text { Decoction, } \\
\boldsymbol{\mu g} / \mathbf{m L}\end{array}$ & $\begin{array}{c}\text { Infusion, } \\
\mathbf{\mu g} / \mathbf{m L}\end{array}$ & $\begin{array}{c}\text { Dry Extract, } \\
\mathbf{m g} \cdot \mathbf{g}^{-\mathbf{1}}\end{array}$ \\
\hline Caffeic acid & $767.85 \pm 16.12$ & $442.48 \pm 8.84$ & $365.49 \pm 7.13$ & $287.82 \pm 6.04$ & $13.58 \pm 0.29$ \\
Myricetin-3-O-glucuronide & $955.30 \pm 18.15$ & $614.49 \pm 13.52$ & $443.14 \pm 7.09$ & $330.08 \pm 6.93$ & $24.22 \pm 0.39$ \\
Agrimoniin & $2388.68 \pm 54.93$ & $1846.76 \pm 38.78$ & $180.24 \pm 4.59$ & $105.70 \pm 2.53$ & $84.12 \pm 1.76$ \\
Ellagic acid & $649.28 \pm 17.53$ & $381.60 \pm 9.15$ & $268.85 \pm 6.45$ & $186.67 \pm 3.73$ & $17.56 \pm 0.40$ \\
Miquelianin & $620.76 \pm 14.27$ & $329.65 \pm 6.92$ & $272.11 \pm 5.98$ & $206.41 \pm 3.50$ & $13.25 \pm 0.32$ \\
Isorhamnetin-3-O-glucuronide & $336.43 \pm 6.39$ & $168.90 \pm 4.39$ & $116.32 \pm 1.98$ & $86.14 \pm 1.98$ & $6.88 \pm 0.16$ \\
Kaempferol-3-O-rhamnoside & $140.93 \pm 3.38$ & $63.83 \pm 1.15$ & $46.17 \pm 1.24$ & $33.46 \pm 0.70$ & $2.18 \pm 0.06$ \\
Total content & 5859.23 & 3847.71 & 1692.32 & 1236.28 & 161.79 \\
\hline
\end{tabular}

The different relative content of agrimoniin on the total content of identified compounds was observed in water- and ethanol-extracted preparations. This parameter was $10.6 \%$ and $8.6 \%$ in decoction and 
infusion, respectively, vs. $40.8 \%$ and $48.0 \%$ in liquid extract and tincture, respectively. The possible reason for these differences is the limited effectiveness of water as an extractant for isolation of ellagitannins from a plant matrix. Furthermore, we allow for the fact of the thermal destruction of ellagitannins within the preparation of decoction and infusion due to high temperature process.

The dry extract of $P$. anserina herb was the most enriched formulation containing $16.18 \%$ of total phenolics, including $8.41 \%$ of agrimoniin, $4.65 \%$ of flavonoids, $1.36 \%$ of caffeic acid, and $1.76 \%$ of ellagic acid. Actual information on the acceptable uptake of various formulations of $P$. anserina [39] allowed us to calculate values of daily consumption of the main groups of active compounds. The results presented in Table 9 show that despite on archaic character of infusion and decoction as medical formulations, their application maximizes uptake values of tannins and flavonoids in 40-60 times greater than after using liquid extract or tincture. Interestingly, despite the fact of the high content of phenolics in dry extract, the daily uptake of flavonoids and total phenols is lower than in the case of infusions or decoctions.

Table 9. Daily uptake of phenolic compounds after application of $P$. anserina preparations.

\begin{tabular}{ccccc}
\hline \multirow{2}{*}{ Preparation } & Recommended Daily & \multicolumn{3}{c}{ Daily Uptake of Compounds, $\mathbf{m g}^{\cdot \mathbf{- 1} \cdot \mathbf{d a y}^{\mathbf{1}}}$} \\
\cline { 3 - 5 } & Uptake of Preparation & Tannins & Flavonoids & Total Phenols \\
\hline Liquid extract & $1-2 \mathrm{~mL}$ & $2.3-4.8$ & $2.1-4.1$ & $5.9-11.7$ \\
Tincture & $2-3 \mathrm{~mL}$ & $3.7-5.5$ & $2.4-3.5$ & $7.7-11.5$ \\
Decoction & $100-150 \mathrm{~mL}$ & $18.0-27.0$ & $87.7-131.5$ & $169.2-254.9$ \\
Infusion & $100-150 \mathrm{~mL}$ & $10.6-15.9$ & $65.6-98.4$ & $123.6-185.4$ \\
Dry extract & $0.5-1 \mathrm{~g}$ & $42.1-84.1$ & $23.3-46.5$ & $80.9-161.8$ \\
\hline
\end{tabular}

These data demonstrate the possibility of adequate substitution of liquid extracts or tinctures by infusions or decoctions at inability of application of the ethanol-containing formulations (children's therapy, allergy to ethanol, et al.).

\section{Experimental Section}

\subsection{General}

Elemental $(\mathrm{C} / \mathrm{H} / \mathrm{O})$ composition was determined using MAT 8200 spectrometer (Thermo Finnigan, Waltham, MA, USA). UV spectra were recorded using a SF-2000 spectrophotometer (OKB Specter, St. Petersburg, Russia). Optical rotations were measured on 341 Series polarimeter (Perkin Elmer, Waltham, MA, USA). MS spectra were registered on a LCQ mass spectrometer (Thermo Finnigan). NMR spectra were recorded on a VXR 500S spectrometer (Varian, Palo Alto, CA, USA). Column chromatography was performed over silica gel 60 (230-400 mesh, Merck, Whitehouse Station, NJ, USA), Sephadex LH-20 (25-100 $\mu \mathrm{m}$, Pharmacia, Uppsala, Sweden), polyamide Woelm (Waters Associates, Inc., Framingham, MA, USA), and Amberlite XAD1180N (Sigma-Aldrich, St. Louis, MO, USA). Finally, pTLC was performed on Sorbfil-A silica gel TLC plates (layer thickness $2 \mathrm{~mm}$; Imid Ltd., Krasnodar, Russia). All chemicals were analytical-grade. Reference compounds with purity greater than $96 \%$ were used. This included commercially available compounds: caffeic acid, myricetin-3-O-glucuronide, ellagic acid, miquelianin, isorhamnetin-3-O-glucuronide, 
kaempferol-3-O-rhamnoside from Sigma-Aldrich (St. Louis, MO, USA); agrimoniin from Chelwill Asia Co., Ltd. (Beijing, China).

\subsection{Plant Material}

The samples of Potentilla anserina L. herb were collected in the flowering period in three Siberian regions of Russian Federation: Yakutia Republic - Churapcha village [Churapcha District; 25.VII.2013, 620278'34" N, 13248'90" E, voucher specimen No Lm/h-905/0515; batch No PA-Y-01(2013)]; Amga village [Amga District; 26.VII.2013, 608992'97" N, 131 $98^{\prime} 52^{\prime \prime}$ E, voucher specimen No Lm/h-905/0615; batch No PA-Y-02(2013)]; Lensk city [Lensk District; 31.VII.2014, 607355'60" N, 114 92'17" E, voucher specimen No Lm/h-905/0715; batch No PA-Y-03(2014)]; Aldan city [Aldan District; 02.VIII.2014, 58 $6407^{\prime} 46^{\prime \prime} \mathrm{N}, 125^{\circ} 45^{\prime} 22^{\prime \prime}$ E, voucher specimen No Lm/h-905/0815; batch No PA-Y-04(2014)]; Buryatia Republic-Ivolginsk village [Ivolginsk District; 25.VII.2012, 517917'24" N, 107²3'71" E, voucher specimen No Lm/h-122/0315; batch No PA-B-05(2012)]; Kurumkan village [Kurumkan District; 29.VII.2013, 54³051'79" N, 110³0'72" E, voucher specimen No Lm/h-122/0415; batch No PA-B-06(2013)]; Kabansk village [Kabansk District; 29.VII.2014, 520583'54" N, 10660'33" E, voucher specimen No Lm/h-122/0515; batch No PA-B-07(2014)]; Horinsk village [Horinsk District; 30.VII.2014, 52 $1550^{\prime} 25^{\prime \prime} \mathrm{N}, 1^{\circ} 9^{\circ} 69^{\prime} 87^{\prime \prime}$ E, voucher specimen No Lm/h-122/0615; batch No PA-B-08(2014)]; Irkutsk oblast'-Kaltuk village [Bratsk

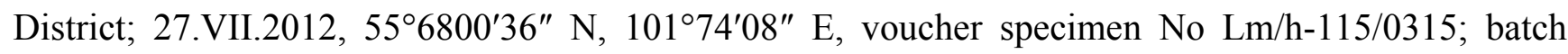
No PA-I-09(2012)]; Odinsk village [Angarsk District; 28.VII.2013, 524587'98" N, 10372'91" E, voucher specimen No Lm/h-115/0415; batch No PA-I-10(2013)]; Tulun village [Tulun District; 30.VII.2014, 545642'43" N, 10053'50" E, voucher specimen No Lm/h-115/0515; batch No PA-I-11(2014)]; Kuitun village [Kuitun District; 31.VII.2014, 54³467'96" N, 10155'07" E, voucher specimen No Lm/h-115/0615; batch No PA-I-12(2014)]. Commercial samples of $P$. anserina herb and preparations were purchased in Company Orokto [Irkutsk, Russua; herb, batch No PA-C-13(2014)], Public Corporation Krasnogorskleksredstva [Moscow, Russia; herb, batch No PA-C-14(2014)], Closed Corporation Vifitekh (Moscow, Russia; tincture) and Limited Liability Company Arura (Ulan-Ude, Russia; liquid extract, dry extract).

\subsection{Extraction and Isolation}

The Yakutian sample [PA-Y-02(2013)] of P. anserina herb (1.64 kg) were air-dried, ground, and extracted with $20 \mathrm{~L}$ of $70 \%$ acetone [40] at $40{ }^{\circ} \mathrm{C}$ two times (90 min each) on water bath with continuous stirring and the extracts were concentrated under reduced pressure to yield $541 \mathrm{~g}$ of crude extract. The crude extract was resuspended in water $(1: 5, v / v)$ and successively partitioned with hexane and EtOAc. The organic layers were dried in vacuo to yield 21.1 and $164.6 \mathrm{~g}$ of hexane and EtOAc fraction residues respectively. The EtOAc fraction $(110 \mathrm{~g})$ was chromatographed over Sephadex LH-20 $(8 \mathrm{~cm} \times 90 \mathrm{~cm})$, eluting with $95 \%$ ethanol, $80 \%$ acetone and $50 \%$ acetone to obtain 3 fractions (fr. 1, 14 g; fr. 2, 63 g; fr. 3, 27 g). Fraction 2 (60 g) was re-chromatographed on a Sephadex LH-20 $(5 \mathrm{~cm} \times 110 \mathrm{~cm})$, eluting with acetone-water $(100: 0 \rightarrow 0: 100)$ to obtain 11 fractions (frs. 2/1-2/11). Fr. 2/3 was chromatographed on pHPLC (Summit HPLC-system with UV-Vis detector (Dionex, Sunnyvale, CA, USA), column LiChrosorb RP-18 (10 mm $\times 250 \mathrm{~mm}, 7 \mu \mathrm{m}$, Merck), T $35^{\circ} \mathrm{C}$, flow 
rate $2 \mathrm{~mL} / \mathrm{min}$; solvent, linear gradient of $5 \%-80 \%$ of $\mathrm{MeCN}$ in $\mathrm{H}_{2} \mathrm{O}$ for $90 \mathrm{~min}$; detector at $270 \mathrm{~nm}$ ) to give 20 frs. (frs. 2/3-1-2/3-20). Fr. 2/3-11 ( $t_{R}$ 31-34 $\mathrm{min}$ ) was re-chromatographed in the same conditions to give agrimoniin (xiii; $3.14 \mathrm{~g}$ ) [31]. Fr. 2/5 was chromatographed on pHPLC to give 20 frs. (frs. 2/5-1-2/5-20). Frs. 2/5-6-2/5-7 ( $\mathrm{t}_{R} 24-29 \mathrm{~min}$ ) were combined and re-chromatographed (pHPLC) to give agrimonic acid B (xii; $102 \mathrm{mg}$ ) [31,40]. Frs. 2/5-8-2/5-9 ( $\left.\mathrm{t}_{R} 29-31 \mathrm{~min}\right)$ were combined and re-chromatographed (pHPLC) to give agrimonic acid A (xi; $164 \mathrm{mg}$ ) [31,40]. Fr. 2/8 was chromatographed on pHPLC to give 20 frs. (frs. 2/8-1-2/8-20). Frs. 2/8-9 ( $\mathrm{t}_{R} 35-39$ min) was re-chromatographed (pHPLC) to give potentillin $(\mathbf{x} ; 54 \mathrm{mg})$ [31]. Fr. 3 (25 g) was subjected on a polyamide column $(500 \mathrm{~g})$, eluting with $\mathrm{H}_{2} \mathrm{O}(12 \mathrm{~L}), 40 \% \mathrm{EtOH}(21 \mathrm{~L})$ and $90 \% \mathrm{EtOH}(7 \mathrm{~L})$. These elutes were brought dried in vacuo to yield 1.4, 14.6 and $7.3 \mathrm{~g}$ of $\mathrm{H}_{2} \mathrm{O}(3 / 1), 40 \% \mathrm{EtOH}(3 / 2)$ and $90 \%$ EtOH fraction (3/3) residue respectively. Fr. 3/1 (1.2 g) was subjected on an Amberlite XAD1180N column (100 g) preconditioned with 90\% ethanol and water, eluting with $\mathrm{H}_{2} \mathrm{O}(1 \mathrm{~L}), 40 \% \mathrm{EtOH}$ $(1.5 \mathrm{~L})$ and $90 \% \mathrm{EtOH}(1 \mathrm{~L})$. These elutes were brought dried in vacuo to yield 655, 308 and $101 \mathrm{mg}$ of $\mathrm{H}_{2} \mathrm{O}(3 / 1-1), 40 \% \mathrm{EtOH}(3 / 1-2)$ and $90 \% \mathrm{EtOH}$ fraction (3/1-3) residue respectively. Fr. 3/1-2 (300 mg) was chromatographed on pHPLC (Summit HPLC-system with UV-Vis detector (Dionex, Sunnyvale, CA, USA), column LiChrosorb RP-18 (10 mm $\times 250 \mathrm{~mm}, 7 \mu \mathrm{m}$, Merck), T $35{ }^{\circ} \mathrm{C}$, flow rate $2 \mathrm{~mL} / \mathrm{min}$; solvent, linear gradient of $5 \%-10 \%$ of $\mathrm{MeCN}$ in $\mathrm{H}_{2} \mathrm{O}$ for $50 \mathrm{~min}$; detector at $316 \mathrm{~nm}$ ) to give 10 frs. [frs. 3/1-2(1)-3/1-2(10)]. Fr. 3/1-2(3)-3/1-2(5) ( $t_{R}$ 15-22 min) were combined and re-chromatographed in the same conditions to give 2-pyrone-4,6-dicarboxylic acid (xvii; $52 \mathrm{mg}$ ) [13]. Fr. 3/2 (14 g) was chromatographed over silica column $(3 \mathrm{~cm} \times 100 \mathrm{~cm})$, eluting with $\mathrm{CHCl}_{3}-\mathrm{MeOH}$ $(100: 0 \rightarrow 0: 100)$ to obtain 11 fractions (frs. 3/2-1-3/2-11). Fr. 3/2-3 was crystallized from $\mathrm{MeOH}$ to give reynoutrin (quercetin-3-O- $\beta$-D-xylopyranoside; v; $11 \mathrm{mg}$ ) [41]. Frs. 3/2-4-3/2-5 were combined and chromatographed over Sephadex LH-20 $(2 \mathrm{~cm} \times 60 \mathrm{~cm})$, eluting with ethanol-water $(90: 10 \rightarrow 10: 90)$ to give miquelianin (quercetin-3-O- $\beta$-D-glucuronopyranoside; iv; $129 \mathrm{mg}$ ) [42], ellagic acid (xvi; $63 \mathrm{mg}$ ) [43] and isoquercitrin (quercetin-3-O- $\beta$-D-glucopyranoside; iii; $27 \mathrm{mg}$ ) [44]. Fr. 3/2-6 was chromatographed over Sephadex LH-20 $(2 \times 60 \mathrm{~cm})$, eluting with ethanol-water $(90: 10 \rightarrow 10: 90)$ to give rutin (quercetin-3-O-rutinoside; ii; $29 \mathrm{mg}$ ) [44] and caffeic acid (xiv; $38 \mathrm{mg}$ ) [45]. Fr. 3/2-9 was chromatographed over Sephadex LH-20 $(2 \mathrm{~cm} \times 50 \mathrm{~cm})$, eluting with ethanol-water $(90: 10 \rightarrow 10: 90)$ to myricetin-3-O- $\beta$-D-glucuronopyranoside (i; $163 \mathrm{mg}$ ) [46] and 3-O-caffeoylquinic acid (xv; $14 \mathrm{mg}$ ) [47]. Frs. 3/3 (7 g) was chromatographed over Sephadex LH-20 $(2 \mathrm{~cm} \times 80 \mathrm{~cm})$, eluting with ethanol-water $(90: 10 \rightarrow 10: 90)$ to give 9 fractions (frs. 3/3-1-3/3-9). Fr. 3/3-2 was separated using pTLC (solvent: toluene-EtOAc-HCOOH 5:4:1) to give kaempferol-3-O- $\alpha$-L-rhamnopyranoside (ix; $37 \mathrm{mg}$ ) [48]. Frs. 3/3-3 and 3/3-4 were combined and chromatographed on pHPLC [Summit HPLC-system with UV-Vis detector (Dionex, Sunnyvale, CA, USA), column LiChrosorb RP-18 $(10 \times 250 \mathrm{~mm}, 7 \mu \mathrm{m}, \mathrm{Merck})$, T $35{ }^{\circ} \mathrm{C}$, flow rate $2 \mathrm{~mL} / \mathrm{min}$; solvent, linear gradient of $5 \%-40 \%$ of $\mathrm{MeCN}$ in $5 \% \mathrm{HCOOH} / \mathrm{H}_{2} \mathrm{O}$ for $60 \mathrm{~min}$; detector at $350 \mathrm{~nm}$ ) to give 12 frs. [frs. 3/3-(3-4)-1-3/3-(3-4)-12]. Fr. 3/3-(3-4)-8 (t $t_{R} 38-42 \mathrm{~min}$ ) was crystallized to give isorhamnetin-3-O- $\beta$-D-glucopyranoside (vii; $18 \mathrm{mg}$ ) [49]. Fr. 3/3-(3-4)-11 ( $\mathrm{t}_{R} 49-52 \mathrm{~min}$ ) was crystallized to give isorhamnetin-3-O- $\beta$-D-glucuronopyranoside (viii; $27 \mathrm{mg}$ ) [42]. Frs. 3/5-3/7 were combined and chromatographed over Sephadex LH-20 $(1 \mathrm{~cm} \times 50 \mathrm{~cm})$, eluting with ethanol-water $(90: 10 \rightarrow 10: 90)$ to give quercitrin (quercetin-3-O- $\alpha$-L-rhamnopyranoside; vi; $34 \mathrm{mg}$ ) [50]. 
Potentillin (x). Off-white powder. $t_{\mathrm{R}} 2.122 \mathrm{~min}$. UV $\left(\lambda_{\max }\right) \mathrm{nm} 220,255$. (-)ESI-MS $\mathrm{m} / z$ 935 [M-H] ${ }^{-}$ ${ }^{1} \mathrm{H}-\mathrm{NMR}\left(500 \mathrm{MHz}, \mathrm{MeOH}-d_{4}\right) \delta 7.31$ (2H, c; H-2', H-6', galloyl), 6.71, 6.62, 6.54, 6.38 (each 1H, c; H-3"', H-3"'', H-3"'"', H-3"'"', HHDP), 6.57 (1H, d, $J=3.5$ Hz; H-1, $\alpha$-Glcp), 5.60 (1H, dd, J = 9.1, 10.2 Hz; H-3, $\alpha-G l c p), 5.36(1 \mathrm{H}, \mathrm{dd}, J=3.5,9.1 \mathrm{~Hz} ; \mathrm{H}-2, \alpha-\mathrm{Glc} p), 5.29(1 \mathrm{H}, \mathrm{dd}, J=6.0,12.9 \mathrm{~Hz}$; H-6a, $\alpha$-Glcp), 5.23 (1H, t, $J=10.2 \mathrm{~Hz}$; H-4, $\alpha-\mathrm{Glc} p), 4.64$ (1H, dd, $J=6.0,10.2 \mathrm{~Hz} ; \mathrm{H}-5, \alpha-\mathrm{Glc} p), 3.82$ $(1 \mathrm{H}, \mathrm{d}, J=13.0 \mathrm{~Hz} ; \mathrm{H}-6 \mathrm{~b}, \alpha-\mathrm{Glc} p) .{ }^{13} \mathrm{C}-\mathrm{NMR}\left(125 \mathrm{MHz}, \mathrm{MeOH}-d_{4}\right) \delta 171.7,169.4,169.0,168.5$, 168.0 (carbonyls, $\underline{\mathrm{COO}}$ ), 146.2 (C-3', C-5', galloyl), 147.0, 146.8, 146.5, 146.1 (C-6", C-6"', C-6"'", C-6"'"', HHDP), 145.9, 145.4 (2C), 145.0 (C-4", C-4"', C-4"'", C-4"'", HHDP), 140.7 (C-4', galloyl), 137.4 (2C), 137.0, 136.8 (C-5", C-5"', C-5"'", C-5"'", HHDP), 126.9, 126.5, 126.0, 125.7 (C-2", C-2"', C-2"'", C-2"'"', HHDP), 120.1 (C-1', galloyl), 116.7, 116.5, 115.6, 115.0 (C-1", C-1"', C-1"', C-1"'", HHDP), 110.1 (C-2', C-6', galloyl), 108.9, 108.4, 107.9, 107.5 (C-3", C-3"', C-3"'", C-3"'"', HHDP), 90.5 (C-1, $\alpha$-Glcp), 75.5 (C-3, $\alpha$-Glcp), 74.0 (C-2, $\alpha$-Glc $p$ ), 70.7 (C-5, $\alpha$-Glc $p$ ), 68.7 (C-4, $\alpha$-Glc $p$ ), 63.0 (C-6, $\alpha-\mathrm{Glc} p)$.

Agrimonic acid $A$ (xi). Off-white powder. $t_{\mathrm{R}} 1.876 \mathrm{~min}$. UV ( $\left.\lambda_{\max }\right) \mathrm{nm}$ 205, 274. (-)ESI-MS $\mathrm{m} / z 1103$ $[\mathrm{M}-\mathrm{H}]^{-} .{ }^{1} \mathrm{H}-\mathrm{NMR}\left(500 \mathrm{MHz}, \mathrm{MeOH}-d_{4}\right) \delta 7.32(1 \mathrm{H}, \mathrm{d}, J=2.1 \mathrm{~Hz} ; \mathrm{H}-6$ ', DHDG), 7.22 (1H, c; H-6", DHDG), 6.89 (1H, d, $J=2.2$ Hz; H-2', DHDG), 6.72, 6.68, 6.40, 6.32 (each 1H, c; H-3"', H-3"'", H-3"'", H-3"'"', HHDP), 6.55 (1H, d, $J=3.4$ Hz; H-1, $\alpha-G l c p), 5.58$ (1H, dd, $J=9.2,10.1 \mathrm{~Hz}$; H-3, $\alpha$-Glcp), $5.34(1 \mathrm{H}, \mathrm{dd}, J=3.4,9.2 \mathrm{~Hz}$; H-2, $\alpha-\mathrm{Glc} p), 5.27$ (1H, dd, $J=5.9,12.9 \mathrm{~Hz}$; H-6a, $\alpha-G l c p)$, $5.20(1 \mathrm{H}, \mathrm{t}, J=10.1 \mathrm{~Hz}$; H-4, $\alpha-\mathrm{Glc} p), 4.61(1 \mathrm{H}, \mathrm{dd}, J=5.9,10.1 \mathrm{~Hz} ; \mathrm{H}-5, \alpha-\mathrm{Glc} p), 3.80(1 \mathrm{H}, \mathrm{d}$, $J=13.1 \mathrm{~Hz}$; H-6b, $\alpha-\mathrm{Glc} p) .{ }^{13} \mathrm{C}-\mathrm{NMR}\left(125 \mathrm{MHz}, \mathrm{MeOH}-d_{4}\right) \delta 171.9,169.9,169.7,169.2,168.5,168.2$ (carbonyls, OO), 150.1 (C-3', DHDG), 147.7 (C-5', DHDG), 147.3, 147.1 (2C), 146.9 (C-6"', C-6"'", C-6"'"', C-6"'"', HHDP), 145.7, 145.5, 145.2 (2C) (C-4"', C-4'"', C-4"'"', C-4"'"', HHDP), 143.4 (C-5", DHDG), 142.8 (C-3", DHDG), 142.6 (C-4', DHDG), 141.3 (C-4", DHDG), 138.1 (C-2", DHDG), 137.8 (2C), 137.5 (2C) (C-5"', C-5"'", C-5"'"', C-5"'"',, HHDP), 127.7, 127.5, 127.1, 126.9 (C-2"', C-2"'", C-2"'"', C-2"'"', HHDP), 120.9 (C-1', DHDG), 117.0 (C-1", DHDG), 116.9, 116.8, 116.0, 115.4 (C-1"', C-1"',, C-1"'", C-1"'"', HHDP), 112.9 (C-2', DHDG), 110.8 (C-6", DHDG), 109.3 (2C), 109.1,

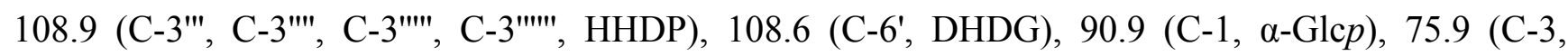
$\alpha$-Glcp), 74.2 (C-2, $\alpha$-Glc $p$ ), 71.0 (C-5, $\alpha$-Glcp), 69.2 (C-4, $\alpha$-Glc $p$ ), 63.5 (C-6, $\alpha$-Glc $p$ ).

Agrimonic acid $B$ (xii). Off-white powder. $t_{\mathrm{R}} 1.563 \mathrm{~min}$. UV ( $\left.\lambda_{\max }\right) \mathrm{nm}$ 205, 274. (-)ESI-MS $\mathrm{m} / z 1103$ $[\mathrm{M}-\mathrm{H}]^{-} .{ }^{1} \mathrm{H}-\mathrm{NMR}\left(500 \mathrm{MHz}, \mathrm{MeOH}-d_{4}\right) \delta 7.29(1 \mathrm{H}, \mathrm{d}, J=2.1 \mathrm{~Hz} ; \mathrm{H}-6$ ', DHDG), $7.24(1 \mathrm{H}, \mathrm{c}$; H-6", DHDG), 6.84 (1H, d, $J=2.2$ Hz; H-2', DHDG), 6.74, 6.70, 6.44, 6.35 (each 1H, c; H-3"', H-3"'", H-3"'", H-3"'"', HHDP), 6.51 (1H, d, $J=3.4$ Hz; H-1, $\alpha$-Glcp), 5.52 (1H, dd, $J=9.2,10.1 \mathrm{~Hz}$; H-3, $\alpha$-Glcp), $5.33(1 \mathrm{H}, \mathrm{dd}, J=3.4,9.2 \mathrm{~Hz}$; H-2, $\alpha$-Glcp), $5.21(1 \mathrm{H}, \mathrm{dd}, J=5.9,12.9 \mathrm{~Hz}$; H-6a, $\alpha$-Glcp), $5.18(1 \mathrm{H}, \mathrm{t}, J=10.1 \mathrm{~Hz}$; H-4, $\alpha-\mathrm{Glc} p), 4.58(1 \mathrm{H}, \mathrm{dd}, J=5.9,10.1 \mathrm{~Hz} ; \mathrm{H}-5, \alpha-G l c p), 3.67(1 \mathrm{H}, \mathrm{d}$, $J=13.1 \mathrm{~Hz}$; H-6b, $\alpha-\mathrm{Glc} p) .{ }^{13} \mathrm{C}-\mathrm{NMR}\left(125 \mathrm{MHz}, \mathrm{MeOH}-d_{4}\right) \delta 171.7,170.3,169.9,169.2,168.6,168.0$ (carbonyls, COO), 149.9 (C-3", DHDG), 147.5 (C-5', DHDG), 147.1, 147.2 (2C), 146.7 (C-6"', C-6"'", C-6"'"', C-6"'"', HHDP), 145.8, 145.4 (2C), 145.1 (C-4"', C-4'"', C-4"'", C-4"'"', HHDP), 143.8 (C-5", DHDG), 143.1 (C-3', DHDG), 142.8 (C-4", DHDG), 141.5 (C-4', DHDG), 138.0, 137.9, 137.6, 137.4 (C-5'", C-5"'", C-5"'", C-5"'"', HHDP), 136.9 (C-2', DHDG), 127.8, 127.5, 127.0, 126.7 (C-2"', C-2"',, C-2"'", C-2"'"', HHDP), 121.4 (C-1', DHDG), 117.2 (C-1", DHDG), 116.6, 116.7, 115.9, 115.2 (C-1"', 
C-1"', C-1"'", C-1"'"', HHDP), 112.4 (C-2", DHDG), 110.7 (C-6", DHDG), 109.4, 109.2, 109.0, 108.7 (C-3"', C-3"'", C-3"'"', C-3"'"', HHDP), 108.4 (C-6', DHDG), 90.5 (C-1, $\alpha-G l c p), 76.2$ (C-3, $\alpha-G l c p)$, 74.6 (C-2, $\alpha$-Glcp), 71.5 (C-5, $\alpha$-Glcp), 68.8 (C-4, $\alpha$-Glcp), 63.2 (C-6, $\alpha$-Glc $p$ ).

Agrimoniin (xiii). Off-white powder. $t_{\mathrm{R}} 2.063 \mathrm{~min}$. UV $\left(\lambda_{\max }\right) \mathrm{nm} 230,268$. (-)ESI-MS $\mathrm{m} / z 1869$ $[\mathrm{M}-\mathrm{H}]^{-} .{ }^{1} \mathrm{H}-\mathrm{NMR}\left(500 \mathrm{MHz}, \mathrm{MeOH}-d_{4}\right) \delta 7.34$ (1H, d, $J=2.1 \mathrm{~Hz}$; H-6", DHDG), 7.20 (1H, c; H-6"', DHDG), 6.91 (1H, d, $J=2.1 \mathrm{~Hz}$; H-2", DHDG), 6.73, 6.70, 6.65, 6.62, 6.60, 6.58, 6.51, 6.46 (each 1H, c; H-3"'", H-3"'"', H-3"'"', H-3"'"'", H-3"'"'"', H-3"'"'"', H-3"'"'"'", H-3"'"'"'"', HHDP), 6.56 (1H, d, $J=4.0 \mathrm{~Hz} ; \mathrm{H}-1, \alpha-\mathrm{Glc} p-1), 6.51$ (1H, d, $J=4.0 \mathrm{~Hz}$; H-1', $\alpha$-Glcp-2), 5.52 (1H, dd, $J=9.6,10.2 \mathrm{~Hz} ; \mathrm{H}-3$ ', $\alpha$-Glcp-2), 5.48 (1H, dd, $J=9.6,10.2 \mathrm{~Hz}$; H-3, $\alpha$-Glcp-1), 5.38 (1H, dd, $J=4.0,9.5 \mathrm{~Hz}$; H-2', $\alpha$-Glc $p$-2), $5.32(1 \mathrm{H}, \mathrm{dd}, J=4.0,9.5 \mathrm{~Hz} ; \mathrm{H}-2, \alpha-\mathrm{Glc} p-1), 5.29$ (1H, dd, $J=6.1,13.0 \mathrm{~Hz} ; \mathrm{H}-6$ ' a, $\alpha-G l c p-2)$, $5.22(1 \mathrm{H}, \mathrm{dd}, J=6.0,13.0 \mathrm{~Hz}$; H-6a, $\alpha-\mathrm{Glc} p-1), 5.20$ (1H, t, $J=9.5 \mathrm{~Hz} ; \mathrm{H}-4$ ', $\alpha-\mathrm{Glc} p-2), 5.14$ (1H, t, $J=9.5 \mathrm{~Hz} ; \mathrm{H}-4, \alpha-\mathrm{Glc} p-1), 4.61(1 \mathrm{H}, \mathrm{dd}, J=6.1,10.2 \mathrm{~Hz} ; \mathrm{H}-5$ ', $\alpha-\mathrm{Glc} p-2), 4.47$ (1H, dd, $J=6.1$, $10.2 \mathrm{~Hz}$; H-5, $\alpha$-Glcp-1), 3.70 (1H, d, $J=13.6 \mathrm{~Hz}$; H-6'b, $\alpha$-Glcp-2), 3.65 (1H, d, $J=13.6 \mathrm{~Hz}$; H-6b, $\alpha$-Glcp-1). ${ }^{13} \mathrm{C}$-NMR (125 MHz, MeOH- $\left.d_{4}\right) \delta 171.4,171.0,169.7$ (2C), 169.5, 169.3, 169.0 (2C), 166.6, 166.3 (carbonyls, COO), 150.1 (C-3", DHDG), 147.9 (C-5", DHDG), 147.5 (4C), 147.1, 146.8 (2C), 146.5 (C-6"'", C-6"'"', C-6"'"', C-6"'"'", C-6"'"'"', C-6"'"'"', C-6"'"'"'", C-6"'"'"'"', HHDP), 146.0, 145.8, 145.5 (3C), 145.1, 144.7, 144.3 (C-4"'", C-4"'"', C-4"'"', C-4"'"'", C-4"'"'"', C-4"'"'"' C-4"'"'"'", C-4"'"'"'"', HHDP), 143.4 (C-5"', DHDG), 142.8 (C-3"', DHDG), 142.6 (C-4", DHDG), 141.3 (C-4"', DHDG), 138.1 (C-2"', DHDG), 137.6 (2C), 137.3, 136.8, 136.5 (3C), 136.2 (C-5"'", C-5"'"', C-5'"'", C-5"'"'", C-5"'"'"', C-5"'"'"', C-5"'"'"'", C-5"'"'"'"', HHDP), 126.7, 126.4, 126.2, 126.0 (2C), 125.7, 125.4 (2C) (C-2"'",C-2"'", C-2"'"', C-2"'"'", C-2"'"'"',C-2"'"'"'",C-2"'"'"'", C-2"'"'"'"', HHDP), 120.9 (C-1", DHDG), 117.0 (C-1"', DHDG), 116.7, 116.5 (2C), 116.0, 115.8, 115.6 (2C), 115.3 (C-1"', C-1"'"', C-1"'"', C-1"'"'", C-1"'"'"', C-1"'"'"', C-1"'"'"'", C-1"'"'"'"', HHDP), 112.9 (C-2", DHDG), 110.8 (C-6"', DHDG), 109.1, 108.7 (4C), 108.5, 108.3 (2C) (C-3"'", C-3"'", C-3"'"', C-3"'"'", C-3"'"'"', C-3"'"'"', C-3"'"'"'", C-3"'"'"'"', HHDP), 108.0 (C-6", DHDG), 90.7 (C-1, a-Glcp-1), 91.2 (C-1', $\alpha$-Glcp-2), 76.0 (C-3', $\alpha$-Glcp-2), 75.6 (C-3, $\alpha$-Glcp-1), 74.4 (C-2, $\alpha$-Glc $p$-1), 74.1 (C-2', $\alpha$-Glc $p$-2), 71.4 (C-5', $\alpha-G l c p-2), 71.0$ (C-5, $\alpha-G l c p-1), 68.9$ (C-4, $\alpha-G l c p-1), 68.5$ (C-4', $\alpha-G l c p-2), 63.3$ (C-6, $\alpha-\mathrm{Glc} p-1), 63.1$ (C-6', $\alpha-\mathrm{Glc} p-2)$.

\subsection{HPLC Apparatus}

The HPLC analyses were performed using the MiliChrom A-02 system (Econova, Novosibirsk, Russia) equipped with a dual low-pressure gradient pump with vacuum degasser, an autosampler, a column compartment, and a UV-Vis detector.

\subsection{MC-RP-HPLC-UV Conditions}

Separation was carried out with ProntoSIL-120-5-C18 AQ analytical column $(1 \mathrm{~mm} \times 60 \mathrm{~mm} \times 5 \mu \mathrm{m}$; Metrohm AG; Herisau, Switzerland). Column temperature was maintained at $35{ }^{\circ} \mathrm{C}$. Elution was conducted using eluent $\mathrm{A}\left(0.2 \mathrm{M} \mathrm{LiClO}_{4}\right.$ in $\left.0.006 \mathrm{M} \mathrm{HClO}_{4}\right)$ and eluent $\mathrm{B}$ (acetonitrile) with a six-step gradient as follows: $0-1.25 \mathrm{~min} 11 \%-18 \% \mathrm{~B}, 1.25-2.25 \mathrm{~min} 18 \% \mathrm{~B}, 2.25-2.5 \mathrm{~min} 18 \%-20 \% \mathrm{~B}$, 2.5-3.0 $\min 20 \%-25 \% \mathrm{~B}, 3.0-4.0 \mathrm{~min} 25 \% \mathrm{~B}, 4.0-5.0 \mathrm{~min} 25 \%-100 \% \mathrm{~B}$. The flow rate was 
$0.6 \mathrm{~mL} \cdot \mathrm{min}^{-1}$. Then, $1 \mu \mathrm{L}$ of each sample was introduced by the autosampler to the column. The column was equilibrated 1 min between injections. UV spectra were recorded in the range of 200-400 nm. Chromatogramms were acquired at $270 \mathrm{~nm}$.

\subsection{Preparation of Standard Solutions for Quantification}

Stock solutions of standards were made by accurately weighing $3 \mathrm{mg}$ of caffeic acid, myricetin-3$O$-glucuronide, agrimoniin, ellagic acid, miquelianin, isorhamnetin-3-O-glucuronide, kaempferol-3-Orhamnoside and dissolving it in $1 \mathrm{~mL}$ of methanol in a volumetric flask. The appropriate amounts of stock solutions were diluted with methanol in order to obtain standard solutions containing 2-2500 $\mu \mathrm{g} / \mathrm{mL}$. As all the compounds used for quantification were well-separated in experiment conditions mixtures of standards were analyzed. Prepared solutions were stored at $4{ }^{\circ} \mathrm{C}$ for no more than $72 \mathrm{~h}$.

\subsection{Sample Preparation for Quantification}

An accurately weighted, dried, and powdered $P$. anserina plant sample (100 $\mathrm{mg})$ was placed in a conical flask. Then $4 \mathrm{~mL}$ of $60 \%$ acetone was added and the mixture was weighted. The sample was then extracted for $30 \mathrm{~min}$ at $40{ }^{\circ} \mathrm{C}$ in ultrasonic device UZV-2.8 (Sapfire, Moscow, Russia) with an ultrasound power of $100 \mathrm{~W}$ and frequency of $35 \mathrm{kHz}$, equipped with a temperature controller and a digital timer. After cooling, the flask weight was reduced to initial sign, and the resultant extract was filtered through a $0.22-\mu \mathrm{m}$ PTFE syringe filter before injection into the HPLC system for analysis.

For preparation of decoction, an accurately weighted, dried, and powdered $P$. anserina plant sample $(1 \mathrm{~g})$ was placed in a conical flask. Then $20 \mathrm{~mL}$ of deionised water was added and the mixture was weighted. The sample was then boiled in a water bath for $30 \mathrm{~min}$. After $10 \mathrm{~min}$ of cooling, the flask weight was reduced to initial sign, and the resultant extract was filtered through a $0.22-\mu \mathrm{m}$ PTFE syringe filter before injection into the HPLC system for analysis.

For preparation of infusion, an accurately weighted, dried, and powdered $P$. anserina plant sample $(1 \mathrm{~g})$ was placed in a conical flask. Then $20 \mathrm{~mL}$ of boiled deionised water was added and the mixture was weighted. The sample was then stirred for $40 \mathrm{~min}$, the flask weight was reduced to initial sign, and the resultant extract was filtered through a $0.22-\mu \mathrm{m}$ PTFE syringe filter before injection into the HPLC system for analysis. Samples of liquid extract and tincture were filtered through a $0.22-\mu \mathrm{m}$ PTFE syringe filter before injection into the HPLC system for analysis.

For preparation of dry extract solution, an accurately weighted dry extract of $P$. anserina (10 $\mathrm{mg}$ ) was placed in an Eppendorf tube, $1 \mathrm{~mL}$ of $60 \%$ ethanol was added, and the mixture was weighted. Then the sample was extracted in an ultrasonic bath for $10 \mathrm{~min}$ at $40{ }^{\circ} \mathrm{C}$. After cooling, the tube weight was reduced to initial sign, and the resultant extract was filtered through a $0.22-\mu \mathrm{m}$ PTFE syringe filter before injection into the HPLC system for analysis.

\subsection{Validation}

For validation of the analytical method, the guidelines established by the International Conference on the Harmonization of Technical Requirements for the Registration of Pharmaceuticals for Human Use (ICH) were employed [51]. The linearity of the method was studied by injecting five known 
concentrations of the standard compounds in the defined range. Results from each analysis were averaged and subjected to regression analysis. Limits of detection (LOD) and quantification (LOQ) were determined using the equations LOD $=3.3 \times S_{Y X} / a$ and LOQ $=10 \times S_{Y X} / a$, respectively, where $S_{Y X}$ is a standard deviation of the response ( $Y$ intercept) and $a$ is a slope of calibration curve. The stability test was performed with one sample solution, which was stored at room temperature and analyzed at $0,2,4,8,12$, and $24 \mathrm{~h}$. The precision of the analytical method was evaluated by intra-day, inter-day, and repeatability test. Intra-day assay was determined by assaying three different concentrations of each compound among the linearity concentrations during the same day, and inter-day assay was analyzed using the same concentrations for intra-day precision on three different days (interval of 1 day) in the same laboratory. The repeatability test of the sample was performed on quintuple experiments of three different concentrations. For analysis of recovery data, the appropriate amounts of the powdered sample of seven phenolic compounds were weighted and spiked with a known amount of each reference compound and then analyzed. Each sample was analyzed in quintuple.

\subsection{Statistical Analysis}

Statistical analyses were performed using a one-way analysis of variance (ANOVA), and the significance of the mean difference was determined by Duncan's multiple range test. Differences at $p<0.05$ were considered statistically significant. The results are presented as mean values $\pm \mathrm{SD}$ (standard deviations) of the three replicates.

\section{Conclusions}

At the present study, a new rapid microcolumn RP-HPLC-UV method has been developed to simultaneously determine seven major phenolic compounds in the Potentilla anserina L. herb. The method showed a good linearity, precision, and accuracy, so it was suitable for quality control of the commercial samples of $P$. anserina L. herb. Ultrasound-assisted extraction was successfully employed to optimize the extraction, and several experimental parameters have been evaluated. The best combination of response functions was $60 \%$ acetone, a liquid-to-solid ratio of $40: 1$, and an extraction of $30 \mathrm{~min}$ at $40{ }^{\circ} \mathrm{C}$ under ultrasound irradiation of $100 \mathrm{~W}$. In addition, 12 samples collected in different Siberian regions and two commercial herbs and preparations have been analyzed. The results warrant further discussion of the appropriate quality control of $P$. anserina pharmaceuticals.

\section{Acknowledgments}

The authors acknowledge the financial support provided by The Russian Foundation for Basic Research, Project No 14-33-50342, and the Presidium of SD RAS, Project No VI.62.1.8.

\section{Author Contributions}

D.N.O. and N.I.K. designed research; N.I.K., S.S.K. and N.K.C. performed research and analyzed the data; D.N.O. and N.I.K. wrote the paper. All authors read and approved the final manuscript. 


\section{Conflicts of Interest}

The authors declare no conflict of interest.

\section{References}

1. Batorova, S.M.; Yakovlev, G.P.; Aseeva, T.A. Handbook of Medicinal Plants of Traditional Tibetan Medicine; Nauka: Novosibirsk, Russia, 2013; pp. 134-136. (In Russian)

2. Anonymous. Bdud Rtsi: Canon of Tibetan Medicine; Vostochnaya Literatura: Moscow, Russia, 2001; pp. 329-334. (In Russian)

3. Makarov, A.A. Herbal Remedies of Yakutian Folk Medicine; Yakutsk: Yakutsk, Russian, 1974; pp. 34-36. (In Russian)

4. Xu, J.-F.; Zheng, X-P.; Liu, W.-D.; Du, R.-F.; Bi, L.-F.; Zhang, P.-C. Flavonol glycosides and monoterpenoids from Potentilla anserina. J. Asian Nat. Prod. Res. 2010, 12, 529-534.

5. Khaidav, C.; Altanchimeg, B.; Varlamova, T.S. Medicinal Plants in Mongolian Medicine; Ulaanbaatar: Ulaanbaatar, Russia, 1985; pp. 122-123. (In Russian)

6. Kombal, R.; Glasl, H. Flavan-3-ols and flavonoids from Potentilla anserina. Planta Med. 1995, 61, 484-485.

7. Angielczyk, M.; Bączek, K.; Geszprych, A.; Przybył, J.L.; Węglarz, Z. Chemical diversity of silverweed (Potentilla anserina L.) growing at the edges of Arable fields. Plant. Breed. Seed Sci. 2010, 61, 41-45.

8. Fecka, I. Development of chromatographic methods for determination of agrimoniin and related polyphenols in pharmaceutical products. J. AOAC Int. 2009, 92, 410-418.

9. Krzaczek, W.; Krzaczek, T. Phenolic acids of native species of the Rosa L. genus in Poland. Acta Soc. Bot. Pol. 1979, 48, 327-336.

10. Mari, A.; Lyon, D.; Fragner, L.; Montora, P.; Piacente, S.; Wienkoop, S.; Egelhofer, V.; Weckwerth, W. Phytochemical composition of Potentilla anserina L. analyzed by an integrative GC-MS and LC-MS metabolomics platform. Metabolomics 2013, 9, 599-607.

11. Goncharov, N.F.; Kotov, A.K. Coumarins, carotenoids, and $\beta$-sitosterol from the epigeal parts of some species of the genus Potentilla. Chem. Nat. Compd. 1991, 27, 752.

12. Bate-Smith, E.C. Chromatography and taxonomy in the Rosaceae with the special reference to Potentilla and Prunus. Bot. J. Linn. Soc. 1961, 58, 39-54.

13. Wilkes, S.; Glasl, H. Isolation, characterization, and systematic significance of 2-pyrone-4,6dicarboxylic acid in Rosaceae. Phytochemistry 2001, 58, 441-449.

14. Tunmann, P. Zur Chemie und Pharmakologie von Potentilla anserina. Arch. Pharm. 1954, 287, 392-404.

15. Wang, J.; Zhang, J.; Zhao, B.; Wang, X.; Wu, Y.; Yao, J. A comparison study on microwave-assisted extraction of Potentilla anserina L. polysaccharides with conventional method: Molecule weight and antioxidant activities evaluation. Carbohydr. Polym. 2010, 80, 84-93.

16. Qin, X.; Lv, Q.; Zhang, X.; Chen, F.; Li, L.; Zhang, Y. Study on protective effect of alcohol extract of Potentilla anserina against acute myocardial ischemia/reperfusion-induced myocardial apoptosis in rats. Chin. J. Chin. Mat. Med. 2012, 37, 1279-1284. 
17. Li, J.Y.; Li, Y.; Gong, H.Y.; Zhao, X.B.; Li, L.Z. Protective effects of n-butanol extract of Potentilla anserina on acute myocardial ischemic injury in mice. Chin. J. Integr. Med. 2009, 7, 48-52.

18. Morikawa, T.; Ninomiya, K.; Imura, K.; Yamaguchi, T.; Akagi, Y.; Yoshikawa, M.; Hayakawa, T.; Muraoka, O. Hepatoprotective triterpenes from traditional Tibetan medicine Potentilla anserina. Phytochemistry 2014, 102, 169-181.

19. Youngken, H.W., Jr.; Neva, A.C.; Dauben, H.J., Jr.; Chang, Y.W.; Wenkert, E. The muscle relaxant effects produced by Potentilla anserina extracts. I. Fractionation studies. J. Am. Pharm. Assoc. 1949, 38, 448-451.

20. Chen, J.-R.; Yang, Z.-Q.; Hu, T.-J.; Yan, Z.-T.; Niu, T.-X.; Wang, L.; Cui, D.-A., Wang, M. Immunomodulatory activity in vitro and in vivo of polysaccharide from Potentilla anserina. Fitoterapia 2010, 81, 1117-1124.

21. Zhao, Y.L.; Cai, G.M.; Hong, X.; Shan, L.M.; Xiao, X.H. Anti-hepatitis B virus activities of triterpenoid saponin compound from Potentilla anserine L. Phytomedicine 2008, 15, 253-258.

22. Schimmer, O.; Lindenbaum, M.; Sollner, U. Plants with antimutagenic properties in Salmonella typhimurium: Inhibition of the 2-nitrofluorene-induced mutagenicity with extracts from Potentilla anserina and Alchemilla species. Planta Med. 1993, 59, 684-685.

23. Schimmer, O.; Lindenbaum, M. Tannins with antimutagenic properties in the herb of Alchemilla species and Potentilla anserina. Planta Med. 1995, 61, 141-145.

24. Tomczyk, M.; Leszczyńska, K.; Jakoniuk, P. Antimicrobial activity of Potentilla species. Fitoterapia 2008, 79, 592-594.

25. Sroka, Z.; Franiszek, R. Antiradical and antimicrobial activity of extracts obtained from plant raw materials. Adv. Clin. Exp. Med. 2008, 17, 275-283.

26. Liu, D.L.; Wang, S.; Zhang, L.; Li, L.Z. Chemical composition of n-butanol extract of Potentilla anserina L. and its protective effect of EAhy926 endothelial cells under hypoxia. Afr. Pharm. Pharmacol. 2012, 6, 677-684.

27. Li, L.-Z.; Zhang, L.; Gong, H.-Y.; Li, J.-Y.; Chen, Y.; Zhang, L.; Zhu, Y.; Li, G.-C.; Zhao, C. Anti-hypoxia and anti-oxidation effect of Potentilla anserina L. petroleum fraction and its mechanism. Chin. Pharm. J. 2006, 41, 1462-1464.

28. Piwowarski, J.P.; Granica, S.; Zwierzyńska, M.; Stefańska, J.; Schopohl, P.; Melzig, M.F.; Kiss, A.K. Role of human gut microbiota metabolism in the anti-inflammatory effect of traditionally used ellagitannin-rich plant materials. J. Ethnopharmacol. 2014, 155, 801-809.

29. Proestos, C.; Boziaris, I.S.; Kapsokefalou, M.; Komaitis, M. Natural antioxidant constituents from selected aromatic plants and their antimicrobial activity against selected pathogenic microorganisms. Food Technol. Biotechnol. 2008, 46, 151-156.

30. Aturki, Z.; Rocco, A.; Rocchi, S.; Fanali, S. Current applications of miniaturized chromatographic and electrophoretic techniques in drug analysis. J. Pharm. Biomed. Anal. 2014, 101, 194-220.

31. Okuda, T.; Yoshida, T.; Kuwahara, M.; Memon, M.U.; Shingu, T. Tannins of Rosaceous medicinal plants. I. Structures of potentillin, agrimonic acids A and B, and agrimoniin, a dimeric ellagitannin. Chem. Pharm. Bull. 1984, 32, 2165-2173. 
32. Okuda, T.; Yoshida, T.; Hatano, T.; Iwasaki, M.; Kubo, M.; Orime, T.; Yoshizaki, M.; Naruhashi, N. Hydrolysable tannins as chemotaxonomic markers in the Rosaceae. Phytochemistry 1992, 31, 3091-3096.

33. Lund, K.; Rimpler, H. Tormentillwurzel. Isolierung eines Ellagitannins und pharmakologisches screening. Deutsche Apotheker Zeitung 1985, 125, 105-108.

34. Feng, W.; Zheng, X.; Yoshida, T.; Okuda, T. Five hydrolyzable tannins from Potentilla discolor Bunge. Tianran Chanwu Yanjiu Yu Kaifa 1996, 8, 26-30.

35. Bazylko, A; Piwowarski, J.P.; Filipek, A.; Bonarewicz, J.; Tomczyk, M. In vitro antioxidant and anti-inflammatory activities of extracts from Potentilla recta and its main ellagitannin, agrimoniin. J. Ethnopharmacol. 2013, 149, 222-227.

36. Li, C.D.; Liu, Y.; Shi, Y.P. Simultaneous determination of six alkaloids in Phellodendron amurense by high-performance liquid chromatography. Acta Chromatogr. 2013, 25, 275-285.

37. Kovaleva, A.M.; Abdulkafarova, E.R. Phenolic compounds from Potentilla anserina. Chem. Nat. Compd. 2011, 47, 446-447.

38. Wichtl, M. Herbal Drugs and Phytopharmaceuticals; CRC Press: Boca Raton, FL, USA; London, UK; New York, NY, USA, 2004; pp. 206-206.

39. Mashkovskii, M.D. Medicinal Agents; Novaya Volna: Moscow, Russia, 2000; pp. 299-304. (In Russian)

40. Yoshida, T.; Tanaka, K.; Chen, X.-M.; Okuda, T. Tannins of Rosaceous medicinal plants. V. Hydrolyzable tannins with dehydrogalloyl group from Rosa laevigata Michx. Chem. Pharm. Bull. 1989, 37, 920-924.

41. Yan, X.; Murphy, B.T.; Hammond, J.B.; Vinson, J.A.; Neto, C.C. Antioxidant activities and antitumor screening of extracts from cranberry fruit (Vaccinium macrocarpon). J. Agric. Food Chem. 2002, 50, 5844-5849.

42. Merfort, I.; Wendisch, D. Flavonolglucuronide aus den Blüten von Arnica montana. Planta Med. 1988, 54, 247-250.

43. Zehl, M.; Braunberger, C.; Conrad, J.; Crnogorac, M.; Krasteva, S.; Vogler, B.; Beifuss, U.; Krenn, L. dentification and quantification of flavonoids and ellagic acid derivatives in therapeutically important Drosera species by LC-DAD, LC-NMR, NMR, and LC-MS. Anal. Bioanal. Chem. 2011, 400, 2565-2576.

44. Olennikov, D.N.; Partilkhaev, V.V. Isolation and densitometric HPTLC analysis of rutin, narcissin, nicotiflorin, and isoquercitrin in Caragana spinosa shoots. J. Planar Chromatogr. 2012, 25, 30-35.

45. Olennikov, D.N.; Tankhaeva, L.M.; Agafonova, S.V. Antioxidant components of Laetiporus sulphureus (Bull.: Fr.) Murr. fruit bodies. Appl. Biochem. Microbiol. 2011, 47, 419-425.

46. Zhang, J.; Huang, N.; Lu, J.; Li, X.; Wang, Y.; Yang, L.; Zheng, Y.; Xiao, K. Water-soluble phenolic compounds and their anti-HIV-1 activities from the leaves of Cyclocarya paliurus. J. Food Drug Anal. 2010, 18, 398-404.

47. Olennikov, D.N.; Tankhaeva, L.M.; Stolbikova, A.V.; Petrov, E.V. Phenylpropanoids and polysaccharides from Plantago depressa and P. media growing in Buryatia. Chem. Nat. Compd. 2011, 47, 165-169.

48. Chen, C.-Y.; Hsieh, S.-L.; Hsieh, M.-M.; Hsieh, S.-F.; Hsieh, T.-J. Substituent chemical shift of rhamnosides from the stems of Cinnamomum osmophleum. Chin. Pharm. J. 2004, 56, 141-146. 
49. Olennikov, D.N.; Kashchenko, N.I. New isorhamnetin glucosides and other phenolic compounds from Calendula officinalis. Chem. Nat. Compd. 2013, 49, 833-840.

50. Manguro, L.O.A.; Ugi, I.; Lemen, P. Further flavonol glycosides of Embelia schimperi leaves. Bull. Chem. Soc. Ethiop. 2004, 18, 51-57.

51. International Conference on Harmonization. Q2B(R1): Guideline on validation of analytical procedure - methodology. In ICH Guidelines; ICH Steering Committee: Brussels, Belgium, 2005.

Sample Availability: Samples of P. anserina plants and extracts are available from the authors.

(C) 2014 by the authors; licensee MDPI, Basel, Switzerland. This article is an open access article distributed under the terms and conditions of the Creative Commons Attribution license (http://creativecommons.org/licenses/by/4.0/). 